\title{
Mülkiyetin Tarihsel Gelişimi Üzerine Bir Deneme
}

\section{An Experiment on the Historical Development of Property}

\author{
Elvin Dinler ${ }^{1}$,, Zeynep Çalışkan ${ }^{2}$ (이
}

Öz

Mülkiyet, insanlık tarihi boyunca gerek bireylerin gerekse de toplumların ilgi odağı olmuş, tarihsel süreçte ise birçok dönüşüme uğramıştr. Bu dönüşüm dünya tarihinde yaşanan ekonomik, siyasi ve dini sistemlerden etkilenerek günümüzdeki halini almıştır. Bu nedenle mülkiyet kavramının yaşadığı dönüşümünü inceleyebilmek için insanlık tarihinde yaşanan önemli olaylara, ekonomik, siyasi ve dini sistemlere de bakma gerekliliği ortaya çıkmaktadır. Bu bağlamda, çalışmada Mısır Takviminden günümüze mülkiyet kavramı söz konusu perspektifte ortaya konmuş, yapılan literatür araştırması sonucunda elde edilen bulgularla kronolojik bir deneme çalışması gerçekleştirilmiştir.

\section{Anahtar Kelimeler}

Mülkiyet kavramı, Özel mülkiyet, Ortak mülkiyet

\begin{abstract}
Property has been the center of attention of both individuals and societies throughout world history and has undergone many transformations in the historical process. This transformation has been affected by economic, political and religious systems in world history. Therefore, in order to examine the transformation of the concept of property, it is necessary to contextualise the important events in the history of the world in terms of economic, political and religious systems. In this context, the concept of property has been put forward in the said perspective from the Egyptian calendar to the present and a chronological study has been, carried out with findings obtained from the literature research.
\end{abstract}

\section{Keywords}

The concept of property, Private property, Joint property

1 Sorumlu Yazar: Elvin Dinler (Öğr. Gör. Dr.), Trakya Üniversitesi, İktisadi ve İdari Bilimler Fakültesi, Çalışma Ekonomisi ve Endüstri İlişkileri Bölümü, Edirne, Türkiye. E-posta: elvindinler@gmail.com ORCID: 0000-0002-3490-0547

2 Zeynep Çalışkan (Dr.), İstanbul Üniversitesi, İktisadi ve İdari Bilimler Fakültesi, Çalışma Ekonomisi ve Endüstri İlişkileri Bölümü, İstanbul, Türkiye. E-posta: z.chaliskan@gmail.com ORCID: 0000-0003-2450-7028

Attf: Dinler, E. ve Caliskan, Z. (2019). Mülkiyetin tarihsel gelişimi üzerine bir deneme. Sosyal Siyaset Konferansları Dergisi, 77: 421-452. https://doi.org/10.26650/jspc.2019.77.0019 


\section{Extended abstract}

Property has been one of the priority areas discussed throughout the world's history. Today, while property continues to be discussed in a wide range from land to information, it is acknowledged to be one of the main causes of inequality while at the same time promoting the necessity of the axis of neo-liberal policies. In this context, the concept of property has been evaluated in a wider perspective. Thus, this study aims to guide the need to examine the concept from a wider perspective in subsequent research. The scope of the study is to evaluate the transformations that have taken place in the history of the world from the Egyptian Calendar to the present, and together with important events, to explain the concept of property in the light of economic, political and religious systems. In this study, literature was searched as a method and a chronological study was carried out.

The transformations that property have gone through in the historical process have been as follows; In the Copper Age, when events were precisely dated, property was concentrated on agricultural land and religious systems, while property on land was observed. With the invention of the plow, productivity and the possibility of using animals in agriculture increased, and in the Bronze Age property extended to land, animals and slaves. Due to drought in the world, It is seen that the aristocracy of land which holds fertile soil, has emerged. ith the emergence of monotheistic religions, debates on joint and private property began, and with the development of trade, property of movable and immovable properties was discussed. The Iron Age is a period in which Chinese philosophy experienced its golden age. In this period, while land property remained the priority, it was seen that with the establishment of Rome, which adopted religious systems as a form of administration, the areas used by families for religious ceremonies were subject to property. Thus, the transfer of property to the family took place, and with the development of the Silk Road, the trade volume expanded and led to the spread of private property. In the Middle Ages, agricultural property became a political organization and feudalism was born as a political organization. Thus, class distinctions were sharpened, and a class society of kings, knights, vassals and peasants emerged, with kings believing that all lands werae given to them by the gods. Scientific developments related to seafaring in the late Middle Ages led to the discovery of new places, the economy developed and an economic system that was different from feudalism emerged. With the use of policies in trade, capital became mobile. In the Middle 
Ages, the power of the church was undeniable because it owned most of the property. In the Early Modern Period however, Luther initiated a protest that allowed the properties of the church to be transferred to kings. The kingdom sold some of these properties and some of them were reserved as kingdom property. In this period, Protestant Calvinists stated that the people who succeeded in prosperity were chosen by God, and the moral equivalent of property was built and the inevitable rise of private property provided the economic accumulation necessary for the Industrial Revolution in the modern age. Adam Smith, one of the important names of the modern era, advocated private property through labor property, and a great gap has emerged in the Liberal State between the working class and the employer. During this period the French Revolution also abolished the property restriction of feudalism. On the one hand, the physiocrats advocated private property and the views of Marxism on joint propery came into prominence. Unemployment with the recent economic crisis has increased the gap between workers and employers.

Poverty and hunger began to increase after the time when the government had no interference with both the property and the economy. However, with the rise of Keynesian policies, welfare state practices have begun and class segregation has decreased somewhat. With the developments in science and technology in the modern age, globalization has entered our lives and borders have disappeared. As a result of the two world wars that took place during this period, colonialism ended and with the emergence of the internet, property became joint property in joint stock companies. In the 21 st century, the discovery and spreading rate of social media inevitably spread to every sphere of life. Property subject to ownership has been evaluated in intellectual, mental and informational fields and its spread through social media has decreased to seconds. Nowadays, the property we are talking about is not only related to movable and immovable property, but to information and even sentences.

As can be seen in the study, important events in world history of property have been affected by economic, political and religious systems and by the ideas of the important philosophers of the ages, as well as transformed these systems. In this context, both property and economic, religious, and political systems need to be evaluated together in a broad perspective. Property has been seen as one of the main causes of inequality throughout the world history and as discussed today. However, there is no consensus on whether property will 
be shared or private, and property we speak of in the 21 st century is now that of intellectual knowledge. The concept of property has undergone many changes to the present day in terms of scope, and its transformation will continue (as is seen from this study). In this context, it is essential to evaluate the studies to be carried out from joint property to private property, from land ownership to information ownership in a broad perspective. 


\section{Mülkiyetin Tarihsel Gelişimi Üzerine Bir Deneme}

\section{Giriş: Mülkiyet Meselesi}

Türkçe'de kullanılan mülkiyet kelimesi, köken itibari ile Arapça bir kelimedir ve mülk sözcüğünden türemiştir. Mülke sahip olan kişilere ise malik ya da melik denmektedir ve hükümdar, egemen ve sahip gibi anlamlar içermektedir. İçerisinde barındırdığ 1 sahiplik anlamından dolayı kişiye özgü bir yanının da olduğunu söylemek yanlış olmayacaktır (Hacak, 2005: 100).

İnsanlar, evrende varlıklarını sürdürebilmek adına üretime katılmak zorundadır. İnsanın varlığı ve varlığını sürdürebilmesi aşamasında gerek duyduğu bu üretim ilişkisi mülkiyet kavramının da doğmasına sebebiyet vermiştir. İlk zamanlarda, ortak mülkiyet olarak var olan bu kavram, zamanla kişilerin kendi özel tasarrufu olarak özel mülkiyet haline dönüşmüştür. Mülkiyetin kime ait olacağı önemli bir tartışma konusu olmuş ve devirlerinin düşünürleri tarafindan da çözüm aranmıştır.

Tek tanrılı dinlerin ortaya çıkması ile birlikte mülkiyetin özel ya da ortaklaşa olması konusunda tartışmalar olmuş, mülkiyetin Allah'a ait olduğu ancak insanların onun mallarına emanetçi olarak getirildiği görüşünden yola çıkılarak, özel mülkiyetin dinler tarafından yasaklanmadığı görüşü ortaya konmuştur (Güriz,1969: 52-54). Roma hukukuna bakıldığında ise, malike verilen mutlak haklar görülmektedir. Feodal dönemde ise mülkiyet hakk1, toprak mülkiyetine dönüşmüş ve bölünmez bir hak olma özelliğinden sapmıştır. Komünistler, mülkiyetin devlete ait olması gerektiğini savunup, özel mülkiyete karşı çıkarlarken (Etgü, 2008: 123 - 124) kapitalistler, özel mülkiyetin önemi üzerine vurgu yaparlar. 21. y.y.' da ise en değerli girdi haline gelen bilgi, fikir ve icat olmuştur. Mülkiyet de bu dönüşümle birlikte, bu yüzyılda biçim değiştirmiş sosyal medyanın da yaygınlaşmasıyla birlikte aktarılan bir düşüncenin, bir cümlenin mülkiyet haline dönüşümü ortaya çıkmıştır. Hangi dönemde olursa olsun, mülkiyet üzerine bir anlaşmaya varıldığını söylemek imkansızdır. Mülkiyet anlayışı, zaman içerisinde değişimlere uğramış, olduğundan, mülkiyet düşüncesinin evrimine insanlık tarihiyle birlikte bakmak, konunun daha iyi anlaşılmasına katkı sağlayacaktır.

Çalışmaya başlangıç itibariyle olayların kesin olarak tarihlendirildiği ilk yıl olan Mısır Takvimiyle başlanmış olup, günümüze kadar gelinmiştir. Bu bağlamda, mülkiyet anlayışında yaşanan dönüşümlerle birlikte, dünya tarihinde yaşanan 
önemli olayların ve dönemlerin ekonomik, siyasi ve dini sistemlerin gelişimi itibariyle kronolojik bir çalışma gerçekleştirilmiştir. Çalışma bağlamında ortaya konan tablolar insanlık tarihinde dönüşüme yol açan önemli olayların yazarlar tarafindan derlenmesiyle oluşturulmuştur. Tablolar oluşturulurken mülkiyetin değişimine doğrudan ya da dolaylı olarak etki eden olayların kronolojik bir perspektifte ortayya konması amaçlanmıştır. Bu açıdan çalışmada kullanılan tablolar sonraki çalışmalarda genişletilebilme özelliği de barındırmaktadır.

\section{Mülkiyet: Mısır Takviminden Bakır Çağı’na}

\begin{tabular}{|c|c|c|c|c|c|c|}
\hline 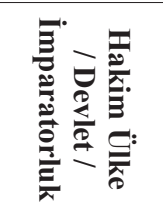 & 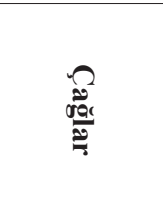 & 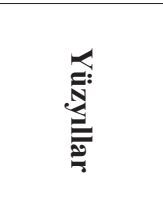 & 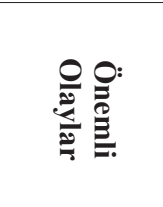 & 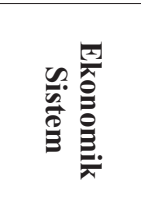 & 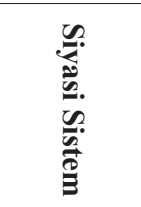 & 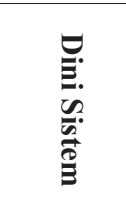 \\
\hline \multirow{2}{*}{$\begin{array}{c}\text { Sümerler ve } \\
\text { Misir şehir } \\
\text { devletleri }\end{array}$} & \multirow{2}{*}{$\begin{array}{l}\text { Bakır Çağ1 } \\
\text { (M.Ö. 51.- } \\
\text { 31. yüzy1l) }\end{array}$} & M.Ö. 43. yу & $\begin{array}{c}\text { Olayların } \\
\text { kesin olarak } \\
\text { tarihlendiği } \\
\text { ilk yıl } \\
\text { (Misır } \\
\text { Takvimi) } \\
\end{array}$ & \multirow{2}{*}{$\begin{array}{c}\text { Tarıma } \\
\text { dayalı ve } \\
\text { tapinak } \\
\text { merkezli } \\
\text { ekonomik } \\
\text { sistem }\end{array}$} & \multirow{2}{*}{$\begin{array}{l}\text { Sümer ve } \\
\text { Misirda } \\
\text { şehir } \\
\text { devletleri } \\
\text { ve tanrilar } \\
\text { adına } \\
\text { toprakları } \\
\text { koruyan } \\
\text { krallar }\end{array}$} & \multirow{2}{*}{$\begin{array}{r}\text { İdoller } \\
\text { ve küçül } \\
\text { kutsal } \\
\text { alanlar }\end{array}$} \\
\hline & & M.Ö. 31. yy & $\begin{array}{l}\text { Sabanın } \\
\text { icadı ile } \\
\text { tarımda } \\
\text { hayvan } \\
\text { gücünden } \\
\text { yararlanıldı }\end{array}$ & & & \\
\hline
\end{tabular}

Mısır takviminin kullanılmaya başlanması ile olayların kesin olarak tarihlendirilmeye başlandığı bu dönem, tarıma dayalı ve tapınak tarafından yönetilen bir ekonomik sisteme sahiptir. M.Ö. 31. yüzyılda sabanın icat edilmesi ile birlikte topraklardan daha fazla verim alınabilmeye başlanmış ve tarım oldukça gelişmiştir. Sabanın icadına kadar odun ile toprağa vurularak yapılan üretim, artık çok daha derine işleyebilen sabanlar sayesinde artmış ve tarımda hayvan gücünden yararlanma imkânı doğmuştur.

Bu dönemde ön planda Sümer ve Mısır şehir devletleri vardır. Bu devletlerde tanrı önemli bir yere sahiptir. Dolayısı ile tanrının yeryüzündeki yansıması olarak kabul gören krallar, bu şehir devletlerinde tanrı adına toprakları ve mülkiyeti koruyan kişiler olarak görülmüşlerdir. Bu dönemde küçük idoller yapılarak tanrılara tapınılmıştır. Bu dönemde büyük tapınaklar söz konusu olmadığından, küçük kutsal alanlarda ibadetler yapılmıştır (Leick, 2003: 6; ed. Kuiper, 2010: 40-65; Ponting, 2011: 66). 
Erken Bronz Çağı ve Mülkiyet

\begin{tabular}{|c|c|c|c|c|c|c|}
\hline 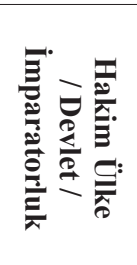 & 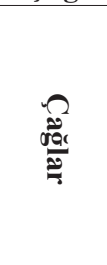 & : & 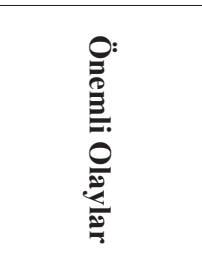 & 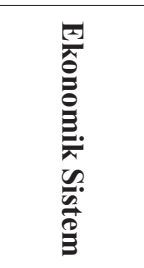 & 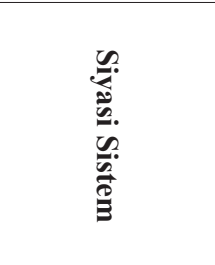 & 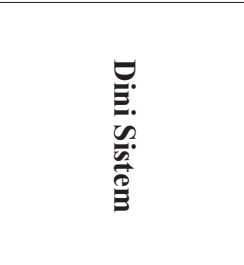 \\
\hline \multirow{4}{*}{$\begin{array}{l}\text { Sümerler } \\
\text { ve M.Ö. } \\
\text { 27. yüzy1l } \\
\text { itibari ile } \\
\text { Eski Misır }\end{array}$} & \multirow{4}{*}{$\begin{array}{c}\text { Erken } \\
\text { Bronz } \\
\text { Çağ1 } \\
\text { (M.Ö. } \\
30 .-23 . \\
\text { Yüzy1l) }\end{array}$} & $\begin{array}{l}3 \\
0: \\
\omega \\
0 \\
< \\
<\end{array}$ & $\begin{array}{l}\text { Sümer'de } \\
\text { erken yaz1 } \\
\text { bulundu }\end{array}$ & \multirow{4}{*}{$\begin{array}{c}\text { Tarıma } \\
\text { dayalı } \\
\text { tapınak } \\
\text { merkezli } \\
\text { bir } \\
\text { ekonomik } \\
\text { sistem söz } \\
\text { konusudur }\end{array}$} & \multirow{3}{*}{$\begin{array}{l}\text { Sümer'de tanrı } \\
\text { adına toprakları } \\
\text { koruyan krallar, } \\
\text { Misır'da } \\
\text { firavunlar }\end{array}$} & \multirow{4}{*}{$\begin{array}{l}\text { İdollere tapınma } \\
\text { dönemidir. Ayrıca } \\
\text { Mısır'da güneş } \\
\text { tanrısı önemli } \\
\text { tanrı olarak } \\
\text { görülmektedir. } \\
\text { Mısır'da } \\
\text { firavunlar tanrı } \\
\text { olarak görülmeye } \\
\text { başladığından } \\
\text { onların } \\
\text { büyüklüğünü } \\
\text { gösteren piramitler } \\
\text { önemli yer tutar }\end{array}$} \\
\hline & & 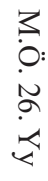 & $\begin{array}{l}\text { Misır'da } \\
\text { büyük piramit } \\
\text { inşa edildi }\end{array}$ & & & \\
\hline & & 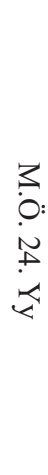 & $\begin{array}{l}\text { Dünyanın } \\
\text { en eski } \\
\text { kayıtlı sosyal } \\
\text { reformları } \\
\text { Lagaş kralı } \\
\text { tarafindan } \\
\text { yapıldı (Vergi } \\
\text { indirimi, } \\
\text { kanunların } \\
\text { yayınlanmas1, } \\
\text { halkın } \\
\text { haklarının } \\
\text { korunması vb.) }\end{array}$ & & & \\
\hline & & 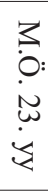 & $\begin{array}{l}\text { İlk imparator } \\
\text { Büyük Sargon }\end{array}$ & & $\begin{array}{l}\text { Akad kralı } \\
\text { Sargon } \\
\text { dünyanın ilk } \\
\text { imparatoru } \\
\text { oldu }\end{array}$ & \\
\hline
\end{tabular}

Sümerlerin ve Eski Mısır devletinin hakim olduğu bir dönem olan erken bronz çağında Sümerler yazıyı bulmuştur. Bu dönemde devletlerde tanrı büyük önem taşımaktadır. Toprakların ve halkın koruyucusu olan tanrılar için büyük ibadethaneler yapılmaya başlanmıştır. Yazının bulunmasını da üretim fazlası olan tahılların tapınaklara bağışlanması ya da emanet olarak bırakılması tetiklemiştir çünkü bu dönemde artan şehir nüfusları nedeni ile tapınaklardaki görevliler, kimin ne kadar ürün getirdiğini hatırlayamaz olmuş, oluşan hırsızlık vb. durumlar da yine bu dönemde yazılı bir kayıt olmadığı için anlaşılamamıştır. $\mathrm{Bu}$ nedenle bu ürünleri kayıt etme gereği doğmuş ve yazı ortaya çıkmıştır 
(King, 2008: 23). Bu dönemde Lagaş kralı olan Urukagina tarihteki ilk sosyal reformları gerçekleştirmiştir. Bu reformların getirilmesinin en önemli sebebi olarak o dönemde Sümerlerin küçük topluluklardan uzaklaşarak, şehir devletleri haline gelmeleri ve zamanla da büyük bir nüfusa sahip olmaları ile birlikte gelişmiş birer devlet haline dönüşmeleri gösterilebilir (Şeker ve Şeker, 2019: 92). Bu dönemde ayrıca Akad kralı Büyük Sargon dünyanın ilk imparatoru olmuştur. $\mathrm{O}$ güne kadar tapınak şehir yönetimi varken kendisi de eski bir memur olan Sargon ile birlikte memur mekanizması ile idare edilen bir devlet sistemi kurulmuştur (Podany, 2018: 71).

\section{Orta Bronz Çă̆ı ve Mülkiyet}

\begin{tabular}{|c|c|c|c|c|c|c|}
\hline 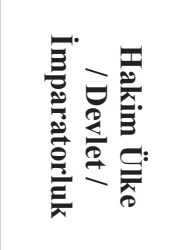 & 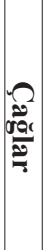 & : & 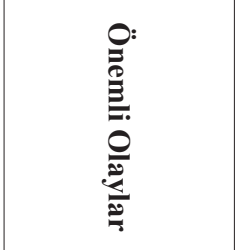 & 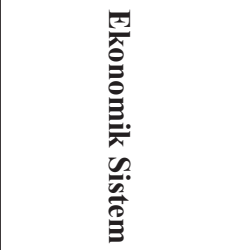 & 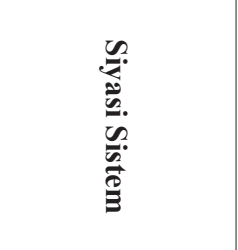 & 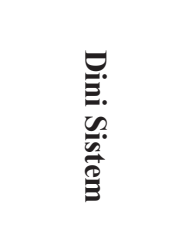 \\
\hline \multirow{8}{*}{$\begin{array}{c}\text { Eski Babil } \\
\text { İmparatorluğu } \\
\text { ve Orta Misir } \\
\text { Krallığ1 }\end{array}$} & \multirow{8}{*}{ 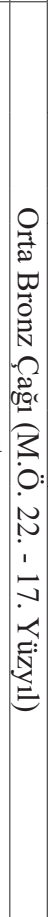 } & $\begin{array}{l}\text { M.Ö. } \\
22 . \\
\text { yy }\end{array}$ & $\begin{array}{c}\text { Dünya çapında } \\
\text { kuraklık (4200 } \\
\text { y1l olayı) }\end{array}$ & $\begin{array}{c}\text { Toprak } \\
\text { aristokrasisi } \\
\text { doğdu }\end{array}$ & \multirow{8}{*}{\begin{tabular}{|c} 
Önemli \\
yerleşim yeri \\
Mezopotamya'dır \\
ve genellikle \\
krallıklarla \\
yönetilen \\
devletler ön \\
plandadır. \\
Babil ve Hitit \\
imparatorlukları \\
gelişmiştir. \\
Misırda \\
firavunluk \\
mevcuttur. M.Ö. \\
20. yüzyıla \\
kadar Sümer \\
Rönesans's olarak \\
adlandırılan ve \\
sanatın, hukukun \\
ve bilimin önem \\
kazandığı dönem \\
hakimdir.
\end{tabular}} & $\begin{array}{c}\text { Büyük } \\
\text { tapınaklar söz } \\
\text { konusudur }\end{array}$ \\
\hline & & $\begin{array}{l}\text { M.Ö. } \\
21 .\end{array}$ & $\begin{array}{c}\text { Mezopotamya'da } \\
\text { Sümer }\end{array}$ & \multirow{7}{*}{$\begin{array}{l}\text { Özellikle tarım } \\
\text { ekonomisi } \\
\text { ön plandadır. } \\
\text { Ancak Babil } \\
\text { imparatorluğunun } \\
\text { gelişmişliği } \\
\text { nedeni ile } \\
\text { çıarılan } \\
\text { Hammurabi } \\
\text { kanunlarının } \\
\text { yaklaşık 100 } \\
\text { maddesi mülkiyet } \\
\text { ve ticaret } \\
\text { ile ilgilidir. } \\
\text { Burada borç, } \\
\text { faiz ve teminat } \\
\text { gibi unsurlar } \\
\text { denetlenir. } \\
\text { Babil ekonomisi } \\
\text { madeni para } \\
\text { ve takas } \\
\text { ekonomisine } \\
\text { dayalıdır. }\end{array}$} & & $\begin{array}{l}\text { Ur'un büyük } \\
\text { Zigurrat'1 }\end{array}$ \\
\hline & & yy & Rönesans'1 & & & \multirow{4}{*}{$\begin{array}{l}\text { Çok tanrılı } \\
\text { dinler ve } \\
\text { tapınaklarda } \\
\text { tapınmaya } \\
\text { dayalı bir dini } \\
\text { sistem söz } \\
\text { konusudur. }\end{array}$} \\
\hline & & $\begin{array}{l}\text { M.O. } \\
20 . \\
\text { yy }\end{array}$ & At arabas 1 icad 1 & & & \\
\hline & & M.Ö. & $\begin{array}{c}\text { Fenike alfabesi } \\
\text { oluşturuldu }\end{array}$ & & & \\
\hline & & yy & $\begin{array}{l}\text { Hititler ortaya } \\
\text { ç1kt1 }\end{array}$ & & & \\
\hline & & $\begin{array}{c}\text { M.Ö. } \\
18 . \\
\text { yy }\end{array}$ & $\begin{array}{l}\text { Hammurabi } \\
\text { kanunları } \\
\text { yürürlüğe girdi }\end{array}$ & & & Hz. İbrahim \\
\hline & & $\begin{array}{c}\text { M.Ö. } \\
17 . \\
\text { yy }\end{array}$ & $\begin{array}{c}\text { G1lgamış Destanı } \\
\text { tamamland } 1\end{array}$ & & & $\begin{array}{c}\text { Hz. Yakup } \\
\text { (İsrailoğulları) }\end{array}$ \\
\hline
\end{tabular}

Bu dönemde dünya çapında çok büyük bir kuraklık söz konusu olmuştur. $\mathrm{Bu}$ kuraklık neticesinde elde kalan verimli topraklar toprak aristokrasisinin doğmasına neden olmuştur. Dönemde tarım ekonomisi ön plandadır. Bununla 
birlikte ticaret de söz konusudur. Fenike alfabesini bulan Fenikeliler deniz ticareti açısından önemli bir medeniyettir. Babil, dönemin en gelişmiş imparatorluğudur. Ticari ve günlük ilişkileri yürütebilmek adına Hammurabi kanunları olarak bilinen kanunlar yürürlüğe girmiştir. Hammurabi kanunları içerisinde 100 'e yakın mülkiyet ve ticaret ile ilgili madde söz konusudur. Dönemin bir diğer önemli devleti olan Hititlerde de mülkiyet ve tapu söz konusudur. Hititler ayrıca maden açısından oldukça zengindir ve dış ülkelere bakır satmaktadır. Toprak, hayvan ve köle mülk konusudur. Hem Hititlerde hem de Babil'de köleler alınır, satılır ve kiralanırdı. Hititlerde kölelerin de mülk sahibi olma hakkı vardır. Aynı zamanda bir köle, bir özgür kadın ile evlenme hakkına da sahiptir. Bu açıdan bakıldığında Hititlerdeki köle anlayışı tam anlamıyla köle değil hizmetçi tanımına uymaktadır (Collins, 2007: 119123; Leick, 2003: 57-63). Aynı dönemde Hz. İbrahim ve bir adı da İsrail olduğu için İsrailoğullarının babası kabul edilen Hz. Yakup ile birlikte milli bir inanç anlayışı söz konusu olmuştur. Tek tanrılı inanç bu dönemde başlamıştır.(Friedman ve Langbert, 2000: 91-92). Yine bu dönemde at arabasının icat edilmesi ve savaşlarda kullanılmaya başlanması, büyük savaşların ve imparatorlukların yıkılması ve yenilerinin kurulması açısından önemli bir adım olmuştur. $\mathrm{Bu}$ dönemde tarihin bilinen ilk yazılı destanı olan Gılgamış destanı tamamlanmıştır. $\mathrm{Bu}$ destanın üç büyük din üzerinde de etkisinin bulunduğu bilinmektedir.

\section{Geç Bronz Çağı ve Mülkiyet}

\begin{tabular}{|c|c|c|c|c|c|c|}
\hline 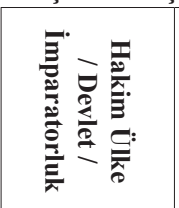 & 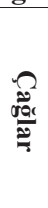 & 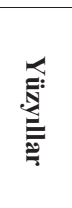 & 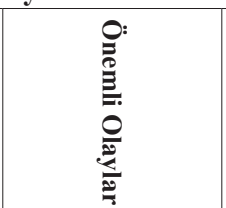 & 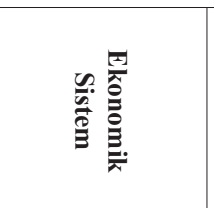 & 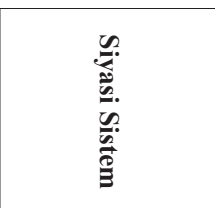 & 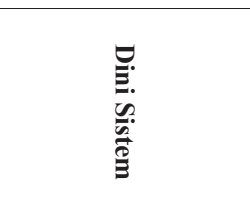 \\
\hline \multirow{5}{*}{$\begin{array}{c}\text { Hitit } \\
\text { İmparatorluğu } \\
\text { ve Yeni Mısır } \\
\text { Krallığ1 }\end{array}$} & \multirow{5}{*}{ 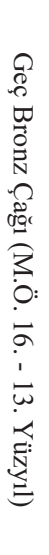 } & $\begin{array}{c}\text { M.Ö. } \\
16 . \\
\text { yy }\end{array}$ & \multirow{2}{*}{$\begin{array}{l}\text { 14. yüzyıllda } \\
\text { Alfabetik } \\
\text { yazı Suriye } \\
\text { ve Filistin'de } \\
\text { yaygınlaştı }\end{array}$} & \multirow{5}{*}{$\begin{array}{l}\text { Ekonomi tarım } \\
\text { ve ticarete } \\
\text { dayalıdır. } \\
\text { Mısırın en büyük } \\
\text { ekonomik gelir } \\
\text { kaynaklarından } \\
\text { birisi sattığı } \\
\text { papirüs } \\
\text { kağıtlarıdır. Hitit } \\
\text { imparatorluğu da } \\
\text { yaptığı değerli } \\
\text { maden ticareti } \\
\text { ve sahip olduğu } \\
\text { verimli toprakları } \\
\text { ile ülkesini } \\
\text { geçindirmektedir. }\end{array}$} & \multirow{5}{*}{$\begin{array}{l}\text { Krallıklar ve } \\
\text { Misır'da da } \\
\text { firavunların } \\
\text { yönetimindeki } \\
\text { devlet ön } \\
\text { plandadır. Devrin } \\
\text { en gelişmiş iki } \\
\text { imparatorluğu } \\
\text { Hitit ve Misır'dır. } \\
\text { Hititleri } \\
\text { tanrısallaştırılmış } \\
\text { krallar yönetirken, } \\
\text { Misırlıları } \\
\text { tanrısallaştırılan } \\
\text { firavunlar } \\
\text { yönetmektedir. }\end{array}$} & Hinduizm başladı \\
\hline & & \multirow{2}{*}{$\begin{array}{c}\text { MÖ. } \\
14 . \\
\text { yy }\end{array}$} & & & & \multirow{4}{*}{$\begin{array}{l}\text { Hz. Musa - } 14 . \\
\text { Yüzyıl ile birlikte } \\
\text { Musevilik başlar } \\
\text { ve İsrail, Babil ve } \\
\text { Misır gibi bölgelerde } \\
\text { egemen olmuştur. } \\
\text { Aynı dönemde } \\
\text { Hititlerde idollere } \\
\text { tapılmaktayken, } \\
\text { Mısırda güneş tanrısı } \\
\text { ve tanrılaştırılmış } \\
\text { firavunlar ön } \\
\text { plandadır }\end{array}$} \\
\hline & & & \begin{tabular}{|c|} 
İlk demir araçlar \\
Hititler tarafindan \\
geliştirildi \\
\end{tabular} & & & \\
\hline & & \multirow[t]{2}{*}{$\begin{array}{c}\text { M.Ö. } \\
13 . \\
\text { yy }\end{array}$} & \begin{tabular}{|c|} 
Hititler ve \\
Misırlılar arasında \\
Kadeş savaşı \\
oldu ve tarihin \\
ilk antlaşması \\
imzalandı \\
\end{tabular} & & & \\
\hline & & & Truva savaş1 & & & \\
\hline
\end{tabular}


Bu dönemde Hititler demir araçları geliştirmiştir. Böylece sağlam olan araçlar yapmışlar ve önemli savaş aletleri de üreterek dönemin en önemli devletlerinden biri haline dönüşmüşlerdir. Bu dönemde bir diğer önemli devlet Mısır'dır. Mısır' da papirüs ticareti önemliyken, Hititlerde çok çeşitli ticaretlerin yapılması söz konusudur. 14. Yüzyıl ile birlikte Hz. Musa'nın önderliğinde Musevilik inancı ön plana çıkmıştır. Bu dönemde Hititler çok tanrılı devlet olarak bilinmekte ve idollere tapmaktayken, Mısırda güneş tanrısı en önemli tanrı olarak bilinmektedir (Briant, 2002: 123; Brier, 1999: 86-90) Aynı dönemde Hindistan'da tam olarak kurucusu bilinmeyen Hinduizm inancı ortaya çıkmıştır. Hinduizm kendi içerisinde kast sistemine sahip olan ve kutsal kitapları olan bir din olarak bugün de dünyada en çok mensubu olan dinlerin arasında yer almaktadır. Bu dönemde ayrıca tarihin ilk yazılı antlaşması Mısırlılar ve Hititler arasında yapılmıştır. Bu antlaşma ile son bulan savaşın sebebi de Mısır'ın Hititlerin sahip oldukları ticaret yollarını ele geçirmek istemeleriydi. Bu dönemde Hititlerde önemli ticaret merkezleri söz konusudur. Ayrıca bu dönemde 10 yıl süren ve bugün de tarihin en önemli savaşlarından biri olarak kabul edilen ve aynı zamanda mitolojik bir hikayeye de sahip olan Truvalılar ve Akalar arasında yapılmış olan Truva savaşı da yapılmıştır. Bu dönemde ortak mülkiyet ve ticaretin gelişmiş olması nedeni ile taşınır mallar üzerinde özel mülkiyet söz konusudur (Warrier, 2007). 
Erken Bronz Çağı ve Mülkiyet

\begin{tabular}{|c|c|c|c|c|c|c|c|}
\hline 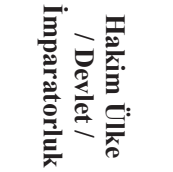 & 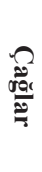 & 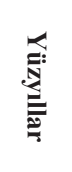 & 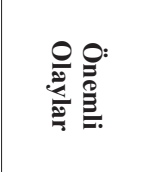 & 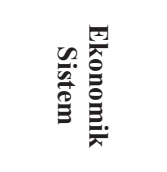 & 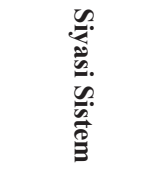 & 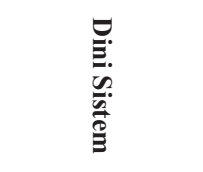 & 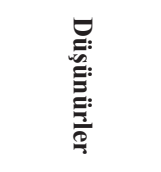 \\
\hline \multirow{9}{*}{$\begin{array}{l}\text { M.Ö. } 12 . \\
\text { Yüzyllda Asur } \\
\text { İmparatorluğu, } \\
\text { sonrasinda } \\
\text { Neo Asur, } \\
\text { Neo Babil } \\
\text { İmparatorluğu } \\
\text { ve M.Ö. 6. } \\
\text { yüzy1l itibari } \\
\text { ile Pers } \\
\text { Akamenid } \\
\text { İmparatorluğu }\end{array}$} & \multirow{9}{*}{ 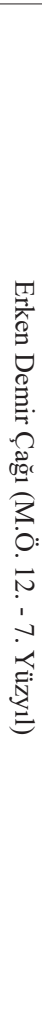 } & $\begin{array}{l}\text { M.Ö. } \\
12 .\end{array}$ & $\begin{array}{c}\text { Yunan } \\
\text { karanlık }\end{array}$ & \multirow{9}{*}{$\begin{array}{c}\text { Kölelik } \\
\text { sisteminin } \\
\text { olduğu, } \\
\text { önemsiz } \\
\text { isslerin } \\
\text { kölelere } \\
\text { yapılddı̆̆ ve } \\
\text { soylular için } \\
\text { çalışmanın } \\
\text { aşağ1llk bir } \\
\text { iş olarak } \\
\text { görüldüğg̈u } \\
\text { tarım ve } \\
\text { ticarete dayal } \\
\text { bir ekonomik } \\
\text { sistem söz } \\
\text { konusudur. }\end{array}$} & \multirow[b]{2}{*}{ Krallık } & \multirow{8}{*}{$\begin{array}{l}\text { Roma ve } \\
\text { Yunan'da çok } \\
\text { tanrıll inanç } \\
\text { varken, İsrail } \\
\text { ve çevresinde } \\
\text { Musevilik, } \\
\text { Hindistan } \\
\text { bölgesinde } \\
\text { Hinduizm ve } \\
\text { 6. yüzyıldan } \\
\text { sonra da Budizm } \\
\text { hakim din olarak } \\
\text { görülmüştür. 7. } \\
\text { Yüzyll itibari } \\
\text { ile İran'da } \\
\text { Zerdüştlük, } 6 . \\
\text { Yüzyıl itibari } \\
\text { ile Çin'de de } \\
\text { Konfüç-yüsçülük } \\
\text { ön plandadır }\end{array}$} & \\
\hline & & $\begin{array}{c}\text { уy } \\
\text { M.Ö. } \\
11 . \\
\text { yy }\end{array}$ & \begin{tabular}{|c} 
çağı başladi \\
Fenike \\
alfabesi \\
geliştirildi
\end{tabular} & & & & \\
\hline & & $\begin{array}{c}\text { M.Ö. } \\
10 . \\
\text { yy }\end{array}$ & $\begin{array}{l}\text { İ̀rail } \\
\text { krallığ1 } \\
\text { kuruldu }\end{array}$ & & $\begin{array}{c}\text { Yahudi } \\
\text { kralları Davut } \\
\text { ve Süleyman } \\
\text { oldu }\end{array}$ & & \\
\hline & & $\begin{array}{l}\text { M.Ö. } \\
\text { 9. yy }\end{array}$ & $\begin{array}{c}\text { İlyada ve } \\
\text { Odyssey } \\
\text { Homeros } \\
\text { tarafindan } \\
\text { yazıldı }\end{array}$ & & \multirow{6}{*}{$\begin{array}{l}\text { Bu dönemde } \\
\text { özellikle } \\
\text { Anadolu'da } \\
\text { krallıklar çok } \\
\text { önemli bir } \\
\text { yere sahiptir. } \\
\text { Büyük } \\
\text { devletler } \\
\text { kurulmuş } \\
\text { ve bunları } \\
\text { krallar ve } \\
\text { imparatorlar } \\
\text { yönetmiştir. }\end{array}$} & & Homeros \\
\hline & & \multirow{2}{*}{$\begin{array}{l}\text { M.Ö. } \\
\text { 8. yy }\end{array}$} & $\begin{array}{l}\text { Roma } \\
\text { krallığ } \\
\text { kuruldu }\end{array}$ & & & & \\
\hline & & & $\begin{array}{c}\text { İlk } \\
\text { olimpiyat } \\
\text { oyunları } \\
\text { yapı1ldı }\end{array}$ & & & & \\
\hline & & $\begin{array}{l}\text { M.Ö. } \\
\text { 7. yy }\end{array}$ & $\begin{array}{c}\text { Çin } \\
\text { felsefesinin } \\
\text { altın çağ } 1 \\
\text { başladı }\end{array}$ & & & & \\
\hline & & \multirow[b]{2}{*}{$\begin{array}{l}\text { M.Ö. } \\
6 . \text { yy }\end{array}$} & \multirow{2}{*}{$\begin{array}{l}\text { Lidyalilar } \\
\text { sikke } \\
\text { parayı } \\
\text { buldu }\end{array}$} & & & & Pythagoras \\
\hline & & & & & & $\begin{array}{l}\text { Kastlar ve Hindu } \\
\text { dininin kendine } \\
\text { özgü biçimlenişi }\end{array}$ & $\begin{array}{c}\text { Lao Tzu, Sun } \\
\text { Tzu, Buddha, } \\
\text { Konfüçyüs }\end{array}$ \\
\hline
\end{tabular}

Bu dönemde Ege'de büyük bir volkanik patlama yaşanmış ve Yunan halkı açlık ve sefaletle karşı karşıya kalmıştır. Bunun üzerine Giritliler, Mikenlerce yağmalanmış ancak Dorlar da Mikenleri yıkmıştır. Bu büyük yıkım neticesinde Yunan toplumları çok uzun bir süre toparlanamamıştır.

Aynı dönemde deniz ticaretinin önemli bir topluluğu olan Fenikelilerin alfabesi geliştirilmiş ve Yahudi kralları Davut ve Süleyman'ın eşliğinde İsrail krallığ1 kurulmuştur. (Finkelstein, 2013: 1-24). Aynı dönemde Romulus tarafindan Roma krallığı kurulmuş ve yine aynı yüzyılda ilk olimpiyat oyunları yapılmıştır. Bu oyunlar, Eleusis Gizemleri ile birlikte antik Roma'nın en önemli dini törenleri arasında yer almıştır. Daha sonra Doğu'da özellikle Konfüçyüs ile birlikte Çin felsefesi altın çağını yaşamıştır. Bu dönemde mülkiyet hakkı, 
toprak mülkiyetine dayalıydı. Roma'da dinler önemli bir yere sahip olması ve her ailenin kutsal bir alanı olduğundan dolayı dini seremonilerden kaynaklanan bir mülkiyet hakkının olduğunu söylemek de yanlış olmayacaktır. Bu dönemde ticaretin gelişmiş olması sebebi ile taşınır mallarda da bir mülkiyet söz konusudur. Ayrıca köleler de mülkiyet konusudur. Devletler genellikle krallar ve imparatorlar tarafından yönetilmiştir. İran'da Zerdüştlük, Çin'de Konfüçyüsçülük, Hindistan'da kast sistemine dayalı olan Hinduizm ve bu kasta karşı çıkan Budizm ile birlikte tek tanrılı bir din olan üç semavi din arasında yerini alan Musevilik ön plandadır. Bu dönemde ticaretin, dini yapılanmanın, bilimsel gelişmelerin ve ekonominin bir arada geliştiği görülmektedir (Roosevelt, 2012: 899; Kuiper, 2011: 21; Scott, 2018: 28).

\section{Klasik Antik Çağ ve Mülkiyet}

\begin{tabular}{|c|c|c|c|c|c|c|c|}
\hline 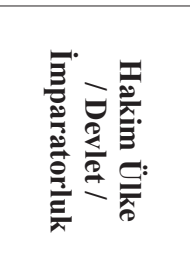 & 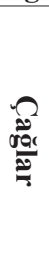 & 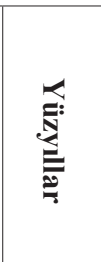 & 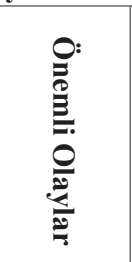 & 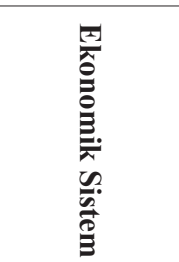 & 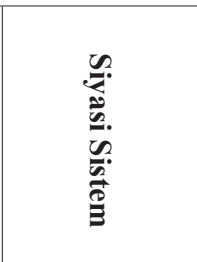 & 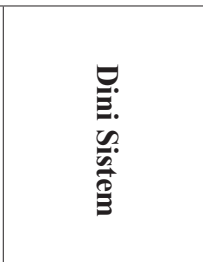 & 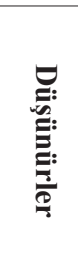 \\
\hline \multirow{6}{*}{$\begin{array}{c}\text { Persler, } \\
\text { Sasaniler, } \\
\text { Roma } \\
\text { İmparatorluğu } \\
\text { ve İskender'in } \\
\text { İmparatorluğu }\end{array}$} & \multirow{6}{*}{ 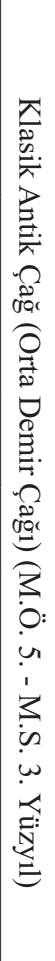 } & \multirow{2}{*}{$\begin{array}{l}\text { M.Ö. } \\
\text { 5. yy }\end{array}$} & $\begin{array}{c}\text { Yunan } \\
\text { - Pers } \\
\text { Savaşları }\end{array}$ & \multirow{6}{*}{$\begin{array}{c}\text { Tarım } \\
\text { ekonomisinin } \\
\text { yanında } \\
\text { ticaret de } \\
\text { oldukça } \\
\text { gelişsiştir. } \\
\text { Özellikle } \\
\text { İpek } \\
\text { Yolu'nda } \\
\text { ticaretin } \\
\text { başlamas1 } \\
\text { ile birlikte } \\
\text { büyük ticaret } \\
\text { merkezleri } \\
\text { kurulmuştur. } \\
\text { Ekonomi } \\
\text { tarım ve } \\
\text { ticarete } \\
\text { dayalıdır. }\end{array}$} & \multirow{6}{*}{$\begin{array}{c}\text { Kral ve } \\
\text { imparatorların } \\
\text { yönetiminin } \\
\text { olduğu daha } \\
\text { profesyonel } \\
\text { siyasi } \\
\text { sistemler söz } \\
\text { konusudur. } \\
\text { Misır'da } \\
\text { toprakların } \\
\text { çok geniş } \\
\text { olmasından } \\
\text { dolayı } \\
\text { rahat idare } \\
\text { edilebilmesi } \\
\text { açısından } \\
\text { Satraplik adı } \\
\text { verilen bir } \\
\text { eyalet sistemi } \\
\text { söz konusudur. } \\
\text { Satraplar soylu } \\
\text { ailelerden } \\
\text { seçilmektedir. } \\
\text { Hükümdarlar } \\
\text { sınırsız } \\
\text { yetkiye } \\
\text { sahiptir. }\end{array}$} & \multirow{5}{*}{$\begin{array}{c}\text { Özellikle } \\
\text { Helenistik } \\
\text { dönemin } \\
\text { hakim olduğu } \\
\text { bu dönemde } \\
\text { önemli Roma } \\
\text { ve Yunan } \\
\text { tanrılarına } \\
\text { tapınılmaktadır } \\
\text { Hindistan'da } \\
\text { Hinduizm } \\
\text { ile Budizm, } \\
\text { İran'da } \\
\text { Zerdüştlük } \\
\text { ve İsrail'de } \\
\text { Musevilik } \\
\text { önemlidir }\end{array}$} & 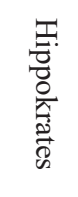 \\
\hline & & & $\begin{array}{l}12 \text { Levha } \\
\text { kanunu } \\
\text { (Medeni } \\
\text { kanunun } \\
\text { atas1) }\end{array}$ & & & & 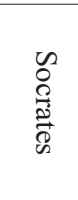 \\
\hline & & \multirow{2}{*}{$\begin{array}{l}\text { M.Ö. } \\
\text { 4. yy }\end{array}$} & $\begin{array}{l}\text { Büyük } \\
\text { İskender }\end{array}$ & & & & \multirow{2}{*}{ 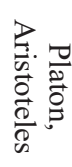 } \\
\hline & & & $\begin{array}{c}\text { Kartaca } \\
\text { savaşları }\end{array}$ & & & & \\
\hline & & $\begin{array}{c}\text { M.Ö.3. } \\
\text { yy }\end{array}$ & \multirow[t]{2}{*}{$\begin{array}{c}\text { İpek } \\
\text { yolunda } \\
\text { ticaret } \\
\text { başlad1 }\end{array}$} & & & & 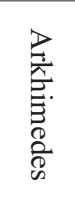 \\
\hline & & $\begin{array}{l}\text { M.Ö. } \\
\text { 1. yy }\end{array}$ & & & & $\begin{array}{l}\text { Hristiyanlık } \\
\text { başladı - Hz. } \\
\text { İsa }\end{array}$ & \\
\hline
\end{tabular}


Bu dönemde ön planda olan devletler Persler, Roma İmparatorluğu ve İskender' in kurduğu imparatorluktur. Ayrıca çok önemli düşünürler yetişmiştir. Sosyalizmin ilk savunucusu olarak da adlandirılabilecek olan Platon, sinıf ayrımının olmadığı bir toplumun mutlu olacağını savunmuştur (Ersoy, 2008: 60-61). Ancak çalışan kesimin mülk sahibi olması gerektiğini ifade ederken, diğer taraftan yöneticilerin mülkünün olmaması gerektiğini savunmaktadır. Ayrıca kölelerin mülk konusu olduğunu ifade etmektedir.

Yine bu dönem yetişmiş olan bir başka ünlü düşünür olan Aristo hocas1 Platon'dan farklı düşünür ve özel mülkiyeti savunur (Erdem, 2012:14). Kişilerin özel mülkiyete sahip olması durumunda çok çalışacaklarını savunur ve kölelerin doğuştan mülkiyet konusu olduğunu düşünür. Ortak mülkiyetin olduğu bir toplumda ise insanların birbirleri ile kavga edeceklerini savunur. Bu dönemin hakim devleti olan Roma' da ise aile mülkiyeti ve özel mülkiyet söz konusudur (Güriz, 1969: 19-25). Yönetilen sınıf olan Plebler'in ayaklanarak yönetici sınıf olan Patricilere karşı baskı yapması sonucunda bugünkü modern hukukun temeli sayılan "Oniki Levha Kanunu” çıkarılmıştır. Bu kanun ile birlikte miras ve vasiyet hakkı tanınmış, kişisel mülkiyet önem kazanmış ve aile reisine malını devretme hakkı verilmiştir. Bu dönemde ayrıca dini olarak da önemli bir gelişme yaşanmış ve Hristiyanlık dini ortaya çıkmıştır. Tüm semavi dinlerde çalışmak zorunludur ve mülkiyet, buna sahip olmayanlar ile paylaştırılmalıdır. $\mathrm{Bu}$ dönemde İpek Yolu'nun gelişmesinden dolayı artan ticaret de özel mülkiyetin yayılmasının en önemli sebeplerinden biridir. 
Geç Antik Çağ ve Mülkiyet

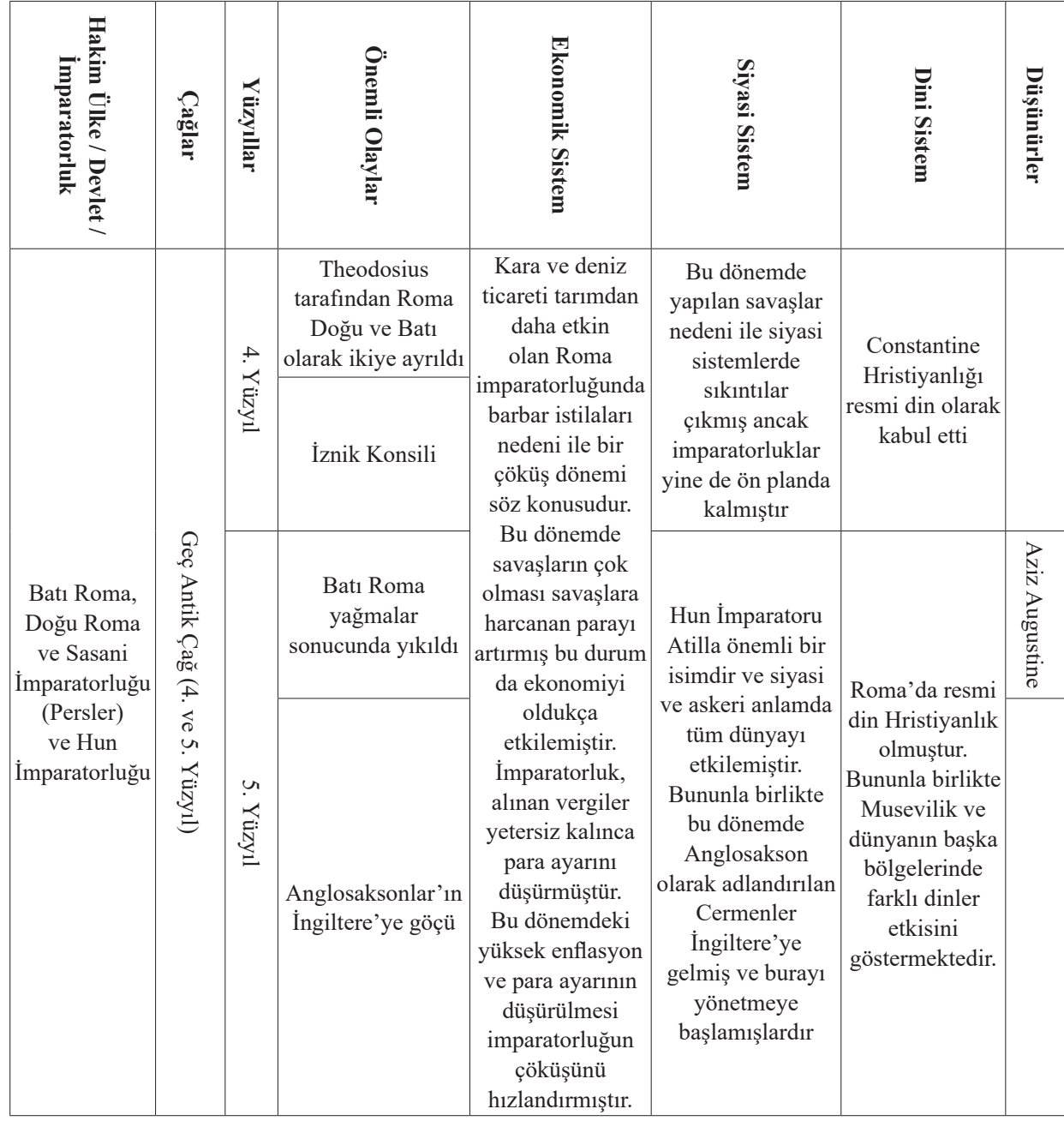

Bu dönemde, dünyanın çeşitli bölgelerinde Pagan inançlar, Budizm, Hinduizm, Musevilik vb. birçok dini inanış biçimi söz konusudur. Ancak Hristiyanlık açısından önemli bir dönemdir. Özellikle İznik Konsili ile birlikte İsa’nın tanrı ile aynı öze sahip olduğu kararlaştırılmıştır. Bu kararın alınma sebeplerinin başında pagan inançların zayıflayarak imparatorlukta dini bir birlik sağlanamaması nedeni ile imparatorluğun zayıflamaya başlaması gelmektedir. Constantine Hristiyanlığı resmi din ilan ederek, dini bir birliktelik kurmayı amaçlamıştır. Hristiyan inancında mülkiyet kavramını sistematik bir biçimde ele alan ilk kişi olan St. Augustine'dir. St. Augustine'e göre mülkiyet tanrınındır ancak özel mülkiyet insan hukukuna dayanmaktadır. Çünkü insanlar kendi özel mülkiyetleri 
olduğu sürece çalışmaya istekli olurlar. Aynı zamanda sahipliğin düzeni sağlayacağını ve özel mülkiyetin barışı teşvik ettiğini ifade etmektedir (Dougherty, 2003: 482-487; Güriz,1969: 19-28).

\section{Erken Orta Çağ ve Mülkiyet}

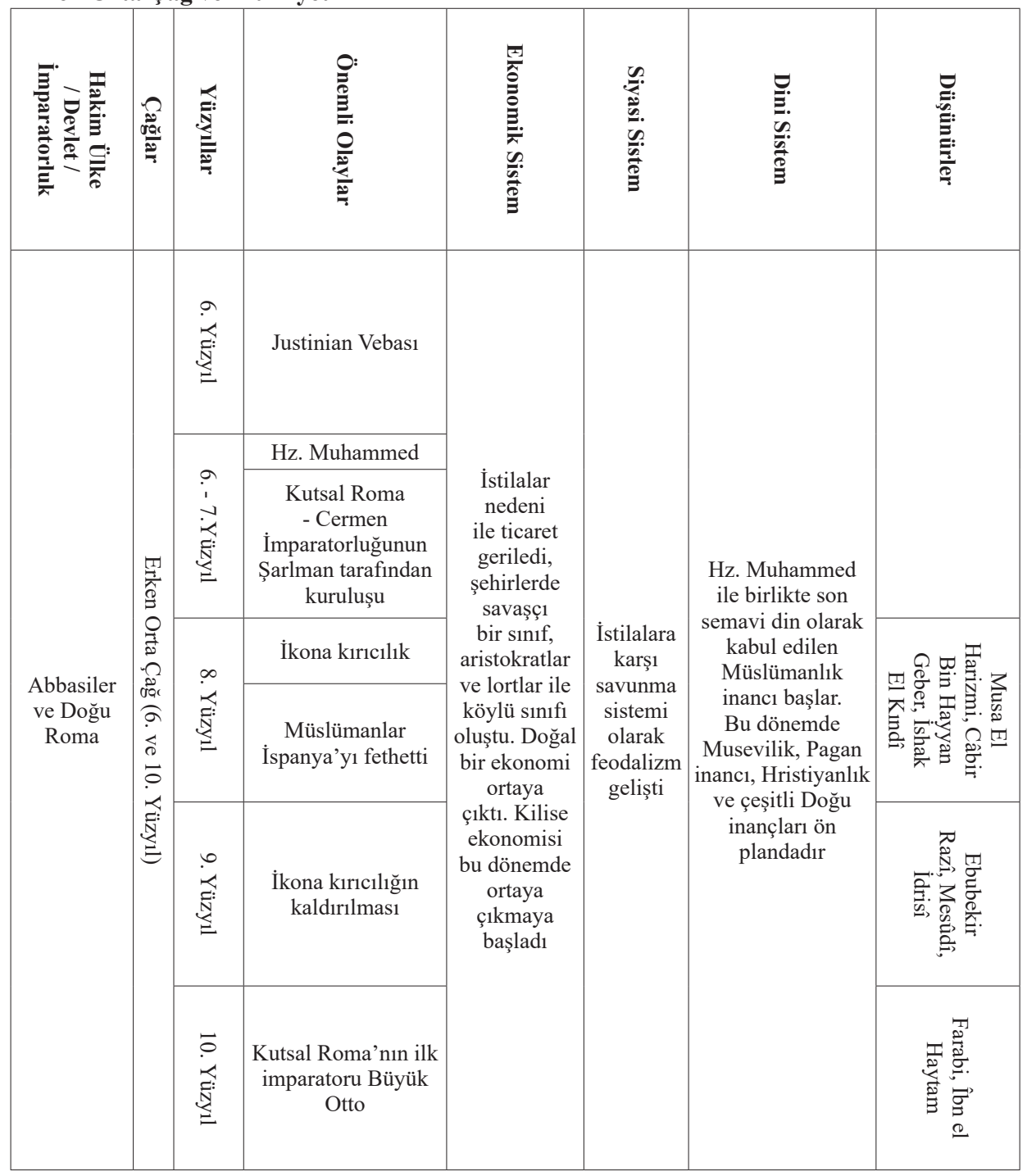

Bu dönemin en önemli devletleri arasında, Emevi hanedanından sonra gelerek İslam devletini yöneten Abbasi hanedanı bulunmaktadır. Abbasilerin başkentleri önceleri Şam olmuşken, daha sonra Bağdat olmuştur. Aynı dönemde, Alman halkının kutsal imparatorluğu olarak da bilinen Kutsal Roma Cermen imparatorluğu da kurulmuş̧tur. Ayrıca 6. yüzyıl'da çok büyük bir veba salgını 
kendisini göstermiş ve dünya nüfusunun çok büyük bir kısmının ölümüne yol açmıştır. 8. yüzyıl'da İspanya halkını ezen krala karşı halk oldukça çaresiz kalmış ve bir kurtarıcı bekler olmuştur. Bu sırada İslamiyet'i Avrupa'ya yaymak isteyen Emevilerden Tarık Bin Ziyad, askerlerini alarak İspanya’yı işgal etmiş ve oraya Endülüs adını vermiştir (Ziya Paşa:2012). Aynı dönemde Cermenlerin Roma'yı istilaları ve Vikinglerin de İngiliz adalarını ve Normandiya'yı işgali söz konusu olmuştur. Bu dönem büyük bir karışıklığın olduğu dönemdir. Cermenlerin, Müslümanların ve Vikinglerin istilalarına karşı Avrupa'da kendi kendini savunma sistemi olarak feodalizm gelişmiştir. Ordulara duyulan ihtiyaç, ağır silahlarla donanmış askerleri gerektirmiş, bu askerlerin eğitimi zor olduğu için bu sınıf üstün bir sınıf haline dönüşmüş ve askeri bir aristokrasi söz konusu olmuştur. Bu askerlere kiliselerden elde edilen toprakların mülk olarak bağışlanması dahi kararlaştırılmıştır. Zamanla, devletin hakim olduğu toprakların her tarafında askerlerin koruduğu yerler ortaya çıkmış, bu alanların etrafına çukurlar açılarak, toprak yığını oluşturulmuş ve gözetleme kuleleri konmuştur. Bununla birlikte erzak deposu ve dış duvar yıkılırsa sığınmak amacı ile son savunma yeri de oluşturulunca, Ortaçağ şatoları ortaya çıkmıştır. Savunma sistemi olarak oluşan bu sistem, siyasi bir örgütlenmeyi de doğurmuş ve Feodalizm olarak adlandırılan siyasi organizasyon ön plana çıkmıştır. Böylece bu sistemde, tepede tüm toprakların Tanrı tarafından kendisine bağışlandığını iddia eden ve bunları parçalara ayırıp vassalara emanet eden bir kral ortaya çıkmıştır. Böylece en tepede bir kral ve altında lortlar, senyörler, şövalyeler, vassallar ve köylülerin yer aldığı bir piramit söz konusu olmuştur. Vassal, aldığg toprağın büyüklüğü oranında lordun ihtiyacı olması durumunda istediği şövalyeleri temin etmeyi vaat etmektedir. Bu açıklamalardan da anlaşılacağ üzere feodal düzende mülkiyet, toprak mülkiyeti olarak görülmektedir. Feodal beyler toprak mülkiyetine sahiptir. Bununla birlikte serf üzerinde de kısmi mülkiyeti söz konusudur. Ancak bu dönemde ilkel dönemden farklı olarak serfin de kısmi mülkiyeti söz konusudur. Aynı dönemde kasabalarda da bir lonca sistemi söz konusudur ve mülkiyet, emeğe dayanmaktadır. Şarlman Irak'ta dünyanın ilk fabrikasını kurmuştur. Ortaçağ'ın bir özelliği olarak ekonomik, siyasi ve dini alanda kiliseler önemli bir kuruluş olmaya başlamışlardır. Sasani Kralı I. Hüsrev Anuşirvan (Nuşirevan) Hindistan'a elçiler göndererek Hintli bilim adamlarını ülkelerine davet etmiştir. Hint bilim adamlarının birden dokuza kadar olan sayıların işaretleri ile hesap usullerini İranlılara öğretmesini sağlamıştır. Arabistan yarımadası ve Ortadoğu' da yaşanan gelişmeler 7. y.y.'da 
Arapları Müslümanlıkla buluşturmuştur. Müslüman Araplar matematik, kimya, astronomi, coğrafya, felsefe gibi bilim dallarında elde ettikleri bilgileri kullanmaya başlamışlardır. Bu dönemde Müslümanlarla birlikte olan Yahudi bilim adamları ve uzmanlarının da yardımıyla bu belgeler Arapça'ya çevrilmiş, 8. y.y.'da Arapların yanı sıra Türk ve İran kökenli dahi insanlar yetiştirilerek Bağdat adeta bilimin merkezi haline gelmiştir (McNeill; 2002: 365-370; Ülgen; 2010: 3-10).

İleri Orta Çă̆ ve Mülkiyet

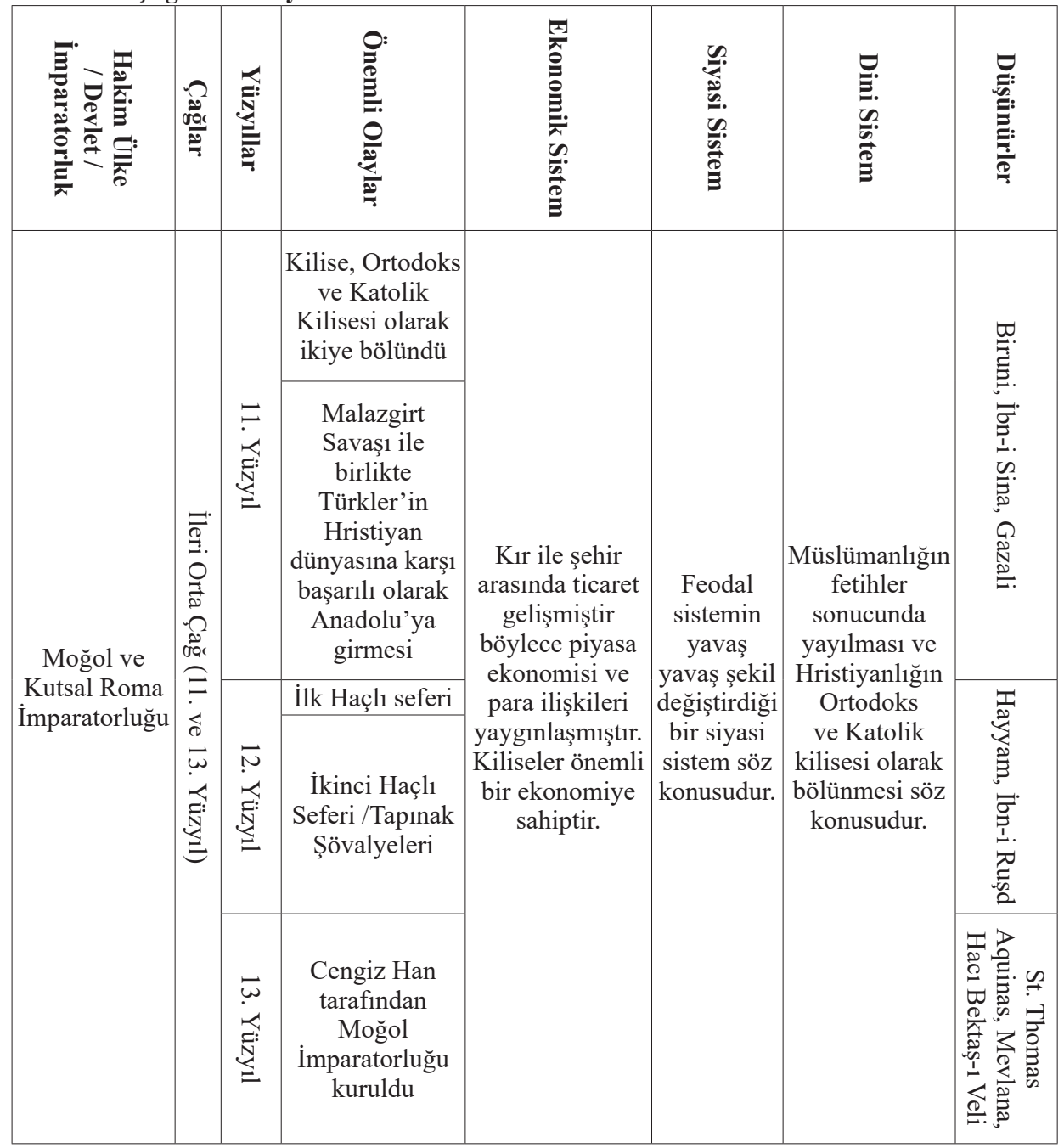

Ortaçağ' 1 en önemli Hristiyan düşünürü St. Thomas Aquinas'tır. O'na göre mülkiyeti herkes kullanabilmelidir. İnsanlar, ortak mülkiyetten hareket ile özel 
mülkiyete kavuşmuştur ve özel mülkiyet bir anlaşma ürünü olarak ortaya çıkmıştır. Ancak mutlak malik Allah’tır. Özel mülkiyet olmalıdır çünkü özel mülkiyet ile birlikte insanlar daha çok çalışır ve böylece üretimde artış söz konusu olur. Üretilen tüm bu ürünler ortaklaşa tüketilirse eşitsizlik de ortadan kalkmış olacaktır (Kılıç ve Demirçelik, 2011:185-186). Bu dönemde kolonileşme ve ticaret tekrar artmaya başlamış ve kasabalar çoğalmaya başlamıştır, ayrıca Papa ile Konstantinopolis patrikleri birbirlerini aforoz etmişler ve böylece Katolik ve Ortodoks bölünmesi yaşanmıştır (Marriot,2015: 65-66). Aynı dönemde birinci haçlı seferleri yapılmış ve kutsal Kudüs şehri, Selahaddin Eyyubi'nin Kudüs'ü tekrar işgaline kadar Hristiyanların eline geçmiştir. Aynı dönemde Asya'da Cengiz Han ön plana çıkmıştır. Haçlı seferleri sonucunda Akdeniz yeniden ticarete açılmıştır ve ticari ilişkiler gelişmiştir. Tarımda da hızlı bir artış olmuştur. Nüfus artmış ve ticaret ve uzmanlaşma ortaya çıkmış, bu da pazar ekonomisini oluşturmuştur. Bu dönemde şehirleşme de hızlanmıştır. Tüccarların bu dönemde şehirlere yerleşmesi ile birlikte merkez haline dönüşmüşlerdir. Sınai faaliyetler de malikanelerden merkezlere kaymış ve feodal olmayan bir yönetim şekli ortaya çıkmaya başlamıştır. Bu dönemde ağır saban ve at koşum sistemi geliştirilmiştir. Su ve rüzgar değirmenleri yaygınlaşmıştır. Çıkrık ve gözlük de bu dönemde bulunmuştur. Ticaret sicili de yine bu sıralarda kurulmuştur. İtalyan tüccarlar çift kayıtlı muhasebe sistemi kullanmış ve bu da önemli bir ticari kayıt sistemi haline gelmiştir. Ortaçağ'ın önemli bir sonucu olarak kiliseler bu dönemde hem ekonomik, hem siyasi hem de dini anlamda önemli bir otorite haline gelmişlerdir. İkinci Haçlı Seferleri sırasında şövalye Hugues du Payens önderliğinde 9 şövalye, Papa II. Innocentius tarafından da onaylanan Tapınak Şövalyeleri olarak adlandırılan askeri bir tarikat haline gelerek Vatikan'a bağlanmıştır. Haçlı seferlerinin sonuna kadar Müslümanlarla savaşan Haçlıları serbest bırakan Selahaddin Eyyübi sadece Tapınakçılar'ı öldürmüştür. Hristiyan hacıların can güvenliğinden sorumlu olan Tapınakçılar daha sonra mal güvenliğini de sağlamıştır ve böylece İngiltere'nin batısından Hindistan'a kadar mal ve evrak karşılığı akreditifler açan bir banka zinciri haline gelmişlerdir. 1080'de Hasan Sabbah'ın kurduğu Haşhaşîler tarikatı 1256' da Moğol hükümdarı tarafından ortadan kaldırılıncaya kadar hüküm sürmüştür.(Faulkner,2012: 121; Barber, 2006). 
Geç Orta Çă̆ ve Mülkiyet

\begin{tabular}{|c|c|c|c|c|c|c|c|}
\hline 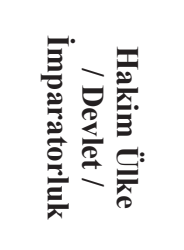 & 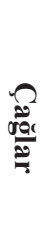 & 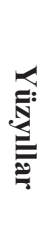 & 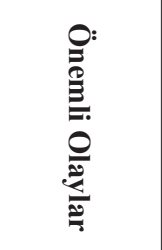 & 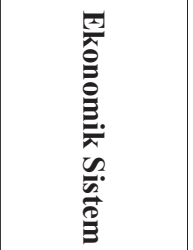 & 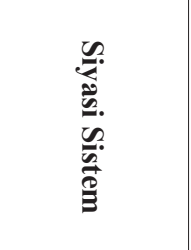 & 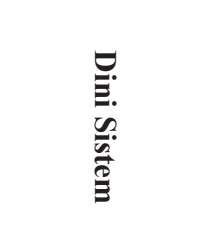 & 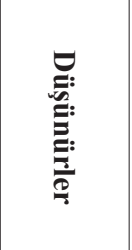 \\
\hline \multirow{5}{*}{$\begin{array}{c}\text { Osmanlı } \\
\text { İmparatorluğu } \\
\text { Kutsal Roma } \\
\text { Cermen } \\
\text { İmparatorluğu }\end{array}$} & \multirow{5}{*}{ 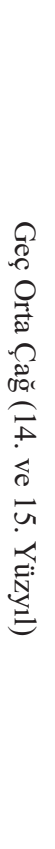 } & \multirow[b]{2}{*}{$\begin{array}{l}\square \\
\vdots \\
\vdots \\
\vdots\end{array}$} & $\begin{array}{c}\text { Yüzyıl } \\
\text { savaşları }\end{array}$ & \multirow{5}{*}{\begin{tabular}{|c} 
Gelişen \\
uluslararası \\
ticaret nedeni \\
ile ekonomi \\
de gelişmiştir \\
ve gelişmiş \\
ticarete dayalı \\
feodalizmden \\
uzaklaşan bir \\
ekonomik \\
sistem söz \\
konusu \\
olmuştur. \\
Bu dönemin \\
en önemli \\
ekonomik \\
gücü olarak \\
kilise \\
görülmektedir
\end{tabular}} & \multirow{5}{*}{$\begin{array}{c}\text { Yeni yerlerin } \\
\text { keşfedilmesi } \\
\text { ile birlikte } \\
\text { sömürgeleştir- } \\
\text { me başlamış } \\
\text { ve gelişen } \\
\text { ticaret nedeni } \\
\text { ile feodal } \\
\text { olmayan } \\
\text { bir yönetim } \\
\text { sistemi ortaya } \\
\text { çlkmıştır. } \\
\text { Kilise en } \\
\text { önemli güçtür }\end{array}$} & \multirow{5}{*}{$\begin{array}{l}\text { Bu dönemde } \\
\text { dünyada } \\
\text { ön plana } \\
\text { ç1kan dinler } \\
\text { Hristiyanlık ve } \\
\text { Müslümanlıktır }\end{array}$} & 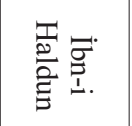 \\
\hline & & & $\begin{array}{c}\text { Kara Ölüm } \\
\text { (Avrupa } \\
\text { nüfusunun } \\
\text { yaklaş1k } \\
\text { \%50'si } \\
\text { öldü) }\end{array}$ & & & & \\
\hline & & \multirow{3}{*}{ 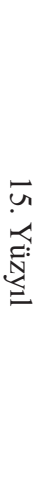 } & $\begin{array}{c}\text { Gutenberg } \\
\text { tarafindan } \\
\text { modern } \\
\text { matbaa } \\
\text { makinesi } \\
\text { icat edildi }\end{array}$ & & & & \\
\hline & & & $\begin{array}{c}\text { İspanyol } \\
\text { engizisyonu }\end{array}$ & & & & \\
\hline & & & $\begin{array}{l}\text { Colomb } \\
\text { Atlantik'i } \\
\text { geçti }\end{array}$ & & & & Da Vinci \\
\hline
\end{tabular}

Bu dönemde ilk saatler ve toplar ortaya çıkmış ve kanalları kapama sistemleri geliştirilmiştir. Gemicilik alanında da teknolojik gelişmeler olmuştur ve yelkenler ve sabit dümenler küreklerin yerini almıştır. Pusulanın Avrupa'da kullanımı yaygınlaşarak yeni yerlerin keşfi kolaylaşmıştır. Manyetik pusula ve haritacılığın gelişmesi ile bilinçli seyahatler yapılmaya başlanmıştır (Köktürk, 2004). Poliçeler ticarette kullanılmaya başlanarak sermaye likit ve uluslararası alanda mobil bir hale dönüşmüştür (Ponting, 2011: 335;). Bu dönemde şehirlerde artan imalat faaliyetleri sonucunda sanayi ölçeği büyüyerek üretim hacmi veba dönemine kadar genişleme kaydetmiştir.

Bu dönemde ünlü İslam düşünürü İbn-i Haldun ön plana çıkmıştır. İbn-i Haldun, emek - mülkiyet ilişkisi konusuna değinmiştir ve çalışanların emek vererek elde ettikleri ürünlerin mülkiyetlerine de sahip olmaları gerektiğini savunmuştur. Devletin bu alandaki görevi ise ahlaki sınırlar içinde mülkiyeti 
tesis edebilmektir. O'na göre mülkiyet hakkı bir kez elde edilince korunması gereken bir niteliğe bürünmektedir ve bu mülk yalnızca çalışarak ve emek verilerek elde edilmelidir (Dalkılınç, 1998; Chapra, 2006).

Gutenberg'in modern matbaa makinesini icat etmesi ile birlikte bilimde bir ilerleme dönemine geçilmiştir. Bu dönemde ortaya çıkan İspanyol engizisyon mahkemelerinde Yahudi ve Müslümanlara karşı ciddi bir kıyım yapılarak, bu toplulukların da Hristiyanlaştııılması amaçlanmıştır. Bu dönemde yaklaşık 200.000 Yahudi İspanya' dan kaçmış ve birçoğu bu dönemin önemli gücü olan Osmanlı'ya sığınmıştır. Ortaçağ' da kiliseler siyasi, dini ve ekonomik açıdan toplumun en önemli kuruluşları haline gelmişlerdir. Bu dönemde keşiflerle birlikte İspanya'ya hazine yağmaya başlamıştır. Fakat bunun sonucunda fiyatlarda genel bir yükseliş baş göstermiştir. Belli bir ticaret hacminde fiyatların paranın arz oranına göre değiş̧eceğini savunan tarihsel teorem de buradan gelmektedir. Böylelikle fiyat artışı ilk İspanya' da ortaya çıkmış ve gümüş ve altın yoluyla da Avrupa'ya sıçramıştır. (Arnold, 1995).

Yeni Çağ ve Mülkiyet

\begin{tabular}{|c|c|c|c|c|c|c|c|}
\hline 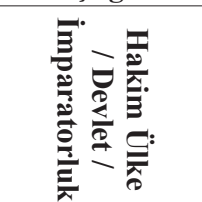 & 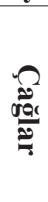 & : & 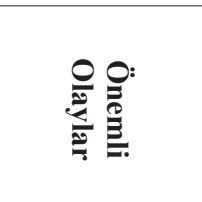 & 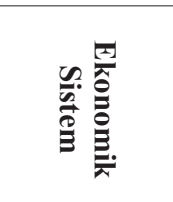 & 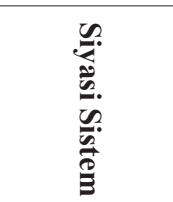 & 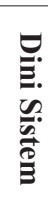 & 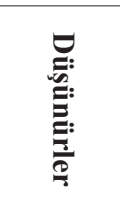 \\
\hline \multirow{7}{*}{$\begin{array}{c}\text { Osmanlı } \\
\text { İmparatorluğu, } \\
\text { İngiliz } \\
\text { İmparatorluğu, } \\
\text { Kutsal Roma } \\
\text { - Cermen } \\
\text { İmparatorluğu }\end{array}$} & \multirow{7}{*}{ 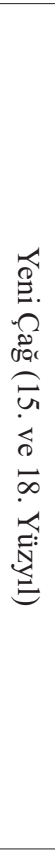 } & ¿র & $\begin{array}{l}\text { Fatih'in } \\
\text { İstanbul'u } \\
\text { Fethi }\end{array}$ & \multirow{7}{*}{$\begin{array}{c}\text { Okyanus } \\
\text { ötesi ticaret } \\
\text { gelişmiş ve } \\
\text { ekonomi } \\
\text { ticarete } \\
\text { dayanmıştır, } \\
\text { sömürgecilik } \\
\text { ve köleci } \\
\text { sistem söz } \\
\text { konusu } \\
\text { olmuştur, } \\
\text { kiliselerin } \\
\text { ekonomik } \\
\text { etkisi } \\
\text { azalmıştır }\end{array}$} & \multirow{7}{*}{$\begin{array}{l}\text { Feodalite } \\
\text { yıkılmış } \\
\text { ve merkezi } \\
\text { krallıklar } \\
\text { güçlenmiştir, } \\
\text { kiliselerin } \\
\text { etkisi } \\
\text { azalmıştır }\end{array}$} & \multirow{7}{*}{ 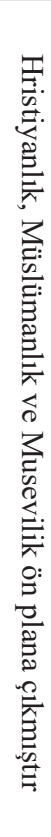 } & 党: \\
\hline & & \multirow{4}{*}{$\begin{array}{l}\text { a } \\
\vdots \\
\vdots \\
\vdots \\
\vdots\end{array}$} & Rönesans & & & & \multirow{3}{*}{ 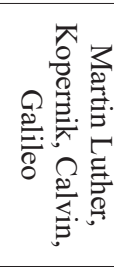 } \\
\hline & & & $\begin{array}{l}\text { Protestan } \\
\text { Reformu }\end{array}$ & & & & \\
\hline & & & $\begin{array}{l}\text { Magellan ve } \\
\text { ekibi dünyanın } \\
\text { etrafını gemi } \\
\text { ile dolaştı }\end{array}$ & & & & \\
\hline & & & $\begin{array}{l}\text { Kopernik } \\
\text { gezegenlerin } \\
\text { güneş } \\
\text { etrafında } \\
\text { döndüklerini } \\
\text { buldu ve } \\
\text { bilimsel } \\
\text { devrim } \\
\text { yaşandı }\end{array}$ & & & & 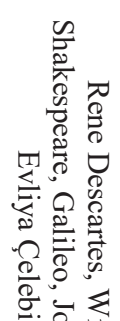 \\
\hline & & 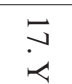 & $\begin{array}{l}\text { Barok dönemi } \\
\text { başladı }\end{array}$ & & & & 总 \\
\hline & & 焉 & $\begin{array}{l}\text { Taj Mahal inşa } \\
\text { edildi }\end{array}$ & & & & $\frac{0}{\hat{\delta}}$ \\
\hline
\end{tabular}


Bu dönemde Hristiyanlık dini için çok önemli bir gelişme yaşanmıştır. 1517 yılında Alman papaz Martin Luther bir protesto başlatmış ve kiliselerin elindeki mülklerin krallığın eline geçmesini sağlamıştır. Bu mülklerin bir kısmı krallık tarafından satılmış, bir kısmı ise krallık mülkü olarak kabul edilmiştir. Protestanlığın kurucusu ve reform hareketinin başlatanı olarak kabul edilen Luther, özel mülkiyeti savunarak ortak mülkiyete karşı gelmektedir. Kendisi, İncil'de ortak mülkiyet ile ilgili bir beyan olmadığını savunur. Hırsılılı̆ın yasaklanmasını da özel mülkiyetin meşru olduğunun ispatı olarak ifade eder. Bu dönemin önemli bir düşünürü olarak da John Calvin görülmektedir. Calvin, ilk kapitalist olarak kabul edilmektedir. O'na göre mülkiyet Tanrı'ya aittir ancak insanlara bağışlanmıştır. Malik, tanrıya ve topluma karşı sorumludur. Mülkiyet hakkı çalışma borcunu doğurmaktadır. Kişi, sahip olduğu bu malları işlemezse tanrıya karşı gelmiş olur ve günahkar sayılır. Calvin, özel mülkiyetin sosyal ve ekonomik adalet için yararlı olduğunu savunmaktadır. Protestan Kalvinistler zenginleşmeyi başaran insanları "Tanrı tarafından seçilmiş” kişiler olarak görüp, diğer insanları da seçilmiş insanlara hizmet edenler olarak kabul ederek, "tasarrufu", "zenginleşmeyi” ve "teknik sermaye birikimini” teşvik eden ahlaki temeli oluşturmuştur. Dönemin bir diğer önemli düşünürü olan John Locke'a göre mülkiyet hakkının temelini emek oluşturmaktadır. Herkesin kendine ait mülkü söz konusudur. Kişinin uzuvları dahi yaradı1ışının mülkiyetidir. Kişilerin emek verip, ürettikleri şeyler onların eseri sayılmalıdır. Kendisi emeğin mülkiyetine inanmaktadır ve o'na göre mülkiyet hakk1, kutsal bir haktır (Güriz, 1969: 82; K1lıç ve Demirçelik, 2011: 188-189).

16. y.y.'dan 18. y.y.'a kadar borsa, dönemin önemli gelişmelerinden biridir. Borsa alışverişlerinin kökeninin senet kırıcılığından geldiği bilinmekle birlikte, özellikle senet kırma işlerinde etkin olarak Yahudilerin bulunduğu belirtilmektedir. $\mathrm{Bu}$ dönemde bilimde yaşanan her gelişme, düşünce, sanat ve inanç alanında da yeniliklere neden olmuştur. Her açidan yenilenme dönemi söz konusudur. Kopernik ve Galileo, güneşin sabit olduğunu ve gezegenlerin onun etrafında döndüğüü savunmuş, Türk - İslam mimarisi önem kazanmış ve Hindistan'da Taj Mahal yapılmıştır. Aynı dönemde, edebi alanda da Descartes ve Shakespeare gibi önemli isimler ortaya çıkmıştır. Matbaanın Avrupa'da kullanılması ile birlikte okuma ve yazma oranı artmış, hümanizm, Rönesans ve Reform hareketleri doğmuştur. Kilise, bu dönemde itibarını kaybetmiştir ve uluslararası denizlere açılma söz konusu olduğu için sömürgecilik başlamıştır. 
Afrika'dan getirilen yerliler Amerika'ya yerleştirilmiştir ve böylece tekrar köle ticareti başlamıştır (Topal, 2007: 23). Avrupa giderek zenginleşmiştir. Sanat, edebiyat ve bilim alanında ciddi gelişmeler yaşanmıştır. Rönesans ile birlikte bilim ve sanat alanlarındaki İslam Dünyası'nın öncülügünü Avrupa almıştır. Eğitim, kiliselerden alınmış ve laik eğitime geçilmiştir. Papanın etkisi azalmıştır.

Yakın Çağ’dan günümüze Mülkiyet

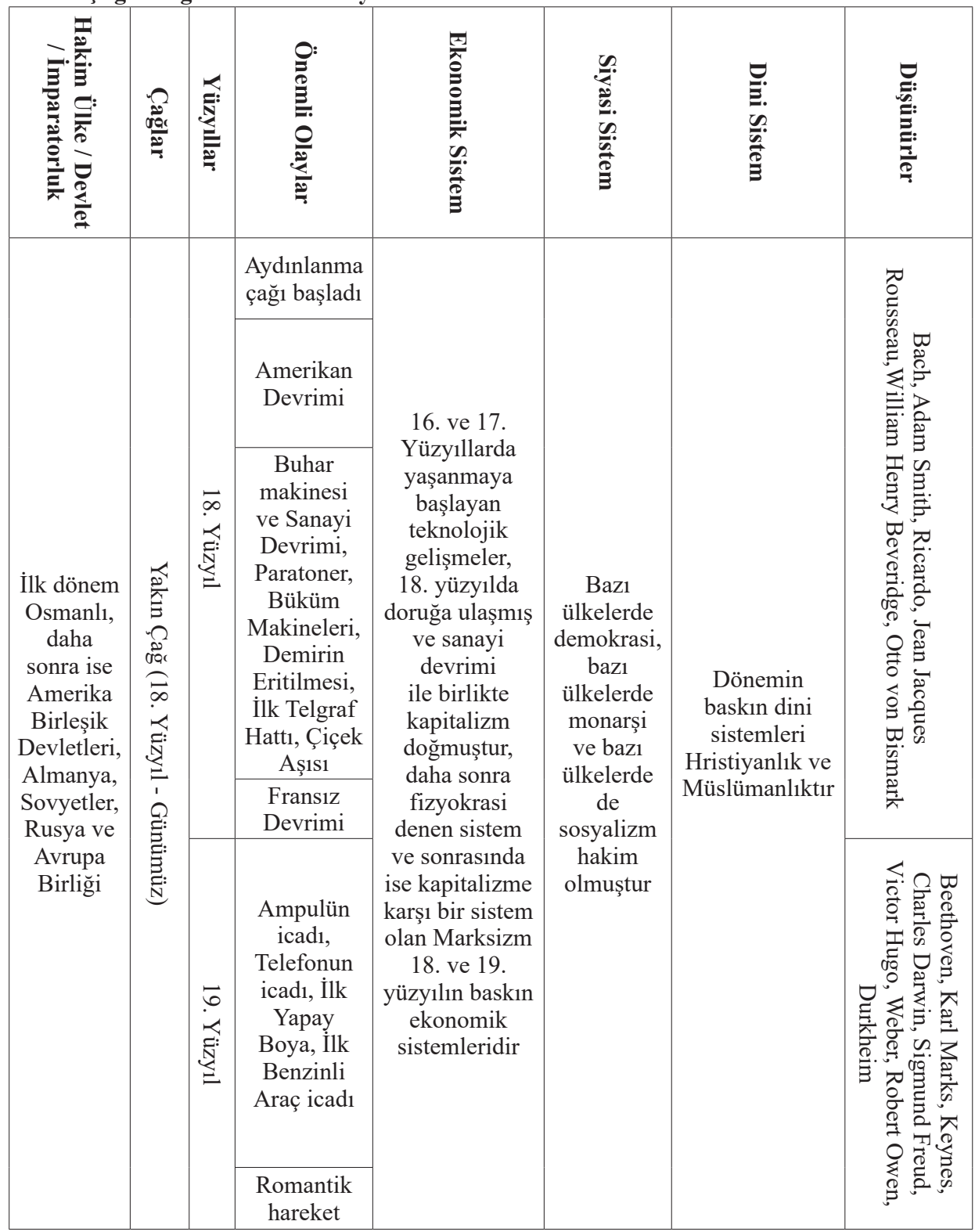


16. ve 17. Yüzyıllarda başlayan teknolojik gelişmeler neticesinde yaşanan değişim, 18. ve 19. yüzy1llarda geri dönülemez bir yola girmiştir ve tüm dünyay1 yakından etkileyen büyük gelişmelere yol açmıştır. Bu dönemde İngiltere' den Amerika'ya giden on üç koloni bağımsızlığını ilan etmiş ve Amerika Birleşik Devletlerini kurmuştur.

Aynı dönemde James Watt buhar makinesini bulmuş ve sanayi devrimi böylece başlamıştır. Sanayi devriminin İngiltere'de başlamasının en büyük sebepleri arasında, o dönemdeki nüfusunun yoğunluğu, sömürgeleri, limanları ve deniz ticareti sayılabilmektedir. 1802 yılında "Factory Act" çıkarılmıştır. Sanayi devrimini Fransız devrimi izlemiştir ve her alanda aydınlanma çağı olmuştur (Hobsbawm, 2003).

1789 Fransız Devrimini izleyen yıllarda başta Fransa olmak üzere İngilizYahudi medeniyetinin taşıyıcıları Farmasonlar bütün Avrupa'ya yayılmaya başlamışlardır. Bu dönemde önemli icatlar da söz konusu olmuştur. Ekonominin bu kadar geliştiği bu dönemde bilim ve edebiyatta da gelişmeler görülmektedir. Dönemin ünlü düşünürlerinden Adam Smith, klasik iktisadın en önemli isimleri arasında yer almaktadır. Adam Smith'e göre emek mülkiyeti, diğer tüm mülkiyetlerin temelini oluşturmaktadır. O'na göre emeğe dayanmayan mülkiyet, adaletsiz bir mülkiyettir. Özel mülkiyetin faydasını savunmaktadır (Adam Smith, 1997: 107). Ayrıca bu dönemde görülen Fransız Devrimi de feodal düzendeki mülkiyet anlayışının değişmesine neden olmuştur. Mülkiyetin tekelliği ve mutlaklığı söz konusu olmuş ve özel mülkiyet feodalizmin yarattığı sınırlama ve yükümlülüklerden kurtulmuştur. Mülkiyetin tüm haklarından malik'in yararlanması söz konusu olmuştur. Fizyokrasiye gelindiğinde de ekonomide sınırsız serbestinin savunulduğu görülmektedir. Fizyokratlar da özel mülkiyetten yanadırlar. Toprak mülkiyetinin refah için çok önemli olduğu savunulmaktadır ve bunun da özel mülkiyete dayanması gerektiği görüşündedirler. Devrin bir diğer önemli ismi olan Rousseau ise mülkiyete farklı açıdan bakmıştır. Ona göre özel mülkiyet, insanların isteklerinin artması sonucunda oluşmaktadır. Kendisi, özel mülkiyeti medeni toplumun temeli olduğundan ötürü kutsal saymıştır ve mülkiyetin rızaya dayalı olması gerektiğini belirtmiştir (Güriz, 1969). Bu dönemde özellikle Sovyet Rusya'da geçerli olan bir sistem olarak Marksizm görülmektedir. Marksizm'e göre özel mülkiyet kesinlikle olmamalı ve toprak mülkiyeti de kaldırılmalıdır. Mülkiyetin birikmesinin önüne geçilmeli ve mülkiyetin devri önlenmelidir. Kişilerin, üretim araçları üzerindeki mülkiyeti 
son bulmalıdır. Özel mülkiyetin malik ve malik olmayan iki ayrı sınıf yaratacağını düşündüğü için Karl Marks, özel mülkiyete karşı çıkmaktadır (Marks ve Engels, 1998: 37-38;).

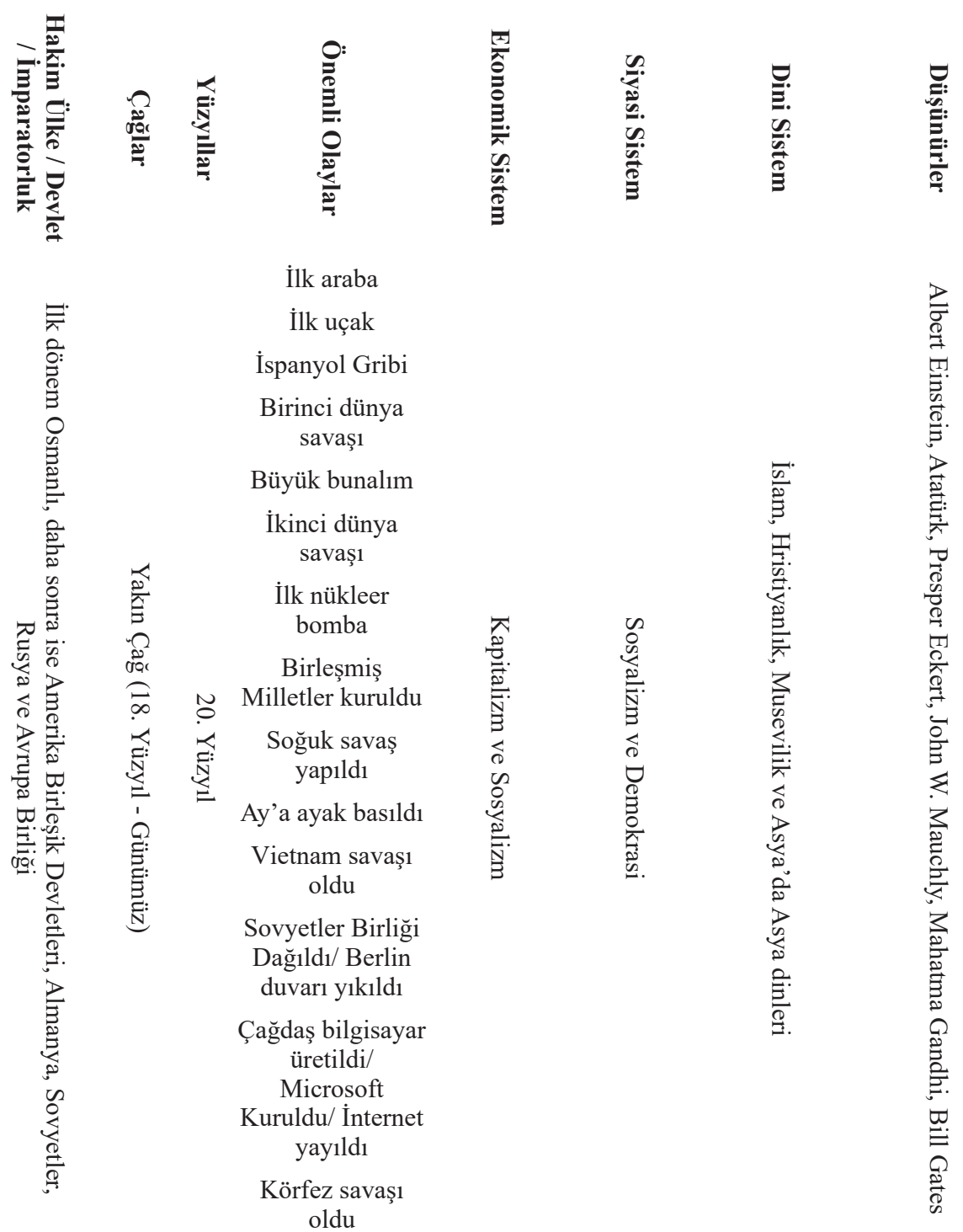

20. ve 21. yüzy1l incelendiğinde özellikle ekonomi ve bilimde yaşanan gelişmelerin, dünyayı da değiştirdiği görülmektedir. 1929 yılında Büyük Buhran özellikle sanayileşmiş ülkeleri esiri altına almış, işsizler ve evsizler ordusu yaratmıştır. Daha sonra Keynesyen politikalar uygulanarak refah devleti 
kavramı önem kazanmıştır. 18. ve 19. yüzyıllarda yaşanan büyük ekonomik ve bilimsel gelişmelerin neticesinde küreselleşme yaşanmış, bilim ve teknoloji çok büyük gelişme göstermiş ve dünyada ülkeler arasındaki sınır kalkmıştır. Tank, ilk kez I. Dünya Savaşı'nda kullanılmıştır. Gerek petrol yatakları, gerekse de sömürgelerin ele geçirilmesi amacıyla bu dönemde iki büyük dünya savaş1 yaşanmıştır. Bu savaşların gizli bir amacı da yeni üretilen silahların denenmesini sağlamaktır. II. Dünya savaşı, nükleer silahların kullanıldığı ve Yahudi soykırımının yapıldığı kanlı bir savaştır. Bu savaşta 50 milyon civarında insan yaşamını kaybetmiştir. Bunun sonucunda sosyal dayanışmayı sağlayabilmek amacı ile Birleşmiş Milletler kurulmuştur. Savaş sonunda Amerika ve Sovyetler Birliği adında iki süper güç ortaya çıkmıştır. Bu iki süper güç daha sonra 46 y1l süren soğuk savaşa girmiştir. Bu savaşlar neticesinde sömürgecilik sona ermeye başlamıştır. Savaş sonunda sosyalist Doğu ile kapitalist Batı'yı ayıran Berlin duvarı yapılmış ve bundan uzun yıllar sonra Doğu Almanya vatandaşlarına geçiş imkanı tanınmış ve binlerce Doğu Alman vatandaşı Polonya, Çekoslavakya, Macaristan ve Yugoslavya gibi ülkelerin başkentlerine akın ederek buralarda bulunan Amerikan, İngiliz ve Fransız büyükelçiliklerine sığınmıştır. Sonuçta artık utanç duvarının anlamı kalmamış ve 1990 yılında resmen yıkılmıştır. Bu dönemde ayrıca Gandhi, ülkesini İngiliz işgalinden kurtarmak için pasif direniş göstermiştir ve Hindistan'ın siyasi ve ruhani lideri olarak görülmüştür. Bu dönemde silah sanayinin gelişmesi birçok savaşın yapılmasına neden olmuştur. Uzaya olan ilgi artmış ve aya ayak basılmıştır. Bununla birlikte, küreselleşme başlamış ve ülkeler arasındaki sınır sanal olarak kalkmıştır. İnternet hayatın içine girmiş, arabalar ve uçaklar yapılmıştır. Böylece ulaşım kolaylaşmış, dünya adeta küçülmüştür. Bu dönemde mülkiyet anlayışı, anonim şirketlerde yoğunlaşan ortak mülkiyet olarak görülmektedir. Ortak mülkiyet içerisinde tasarrufları yöneten yöneticiler ile bu tasarruflardan yararlanan hissedarlar bulunmaktadır. Dolayısıyla yararlanan ve kullanan birbirinden ayrılmıştır. Mülkiyet, yalnızca taşınır ve taşınmaz mallarda değil, aynı zamanda entelektüel mülkiyet olarak da görülmektedir. Fikir, yetenek, bilgi, patent vb. bu haklar kapsamına girmektedir ve bilgi çağında diğer mülkiyet türlerinden daha ön plandadır. Ford Model T’nin seri üretimine de bu dönemde başlanmıştır. Ekim Devrimi ile Rusya'da sosyalistler yönetime el koymuştur. Çar ve Romanov Hanedanı kurşuna dizilerek öldürülmüş ve 300 yıllık Romanov hanedanı sona ermiştir. Türk Kurtuluş Savaşı başlamış ve TBMM açılmıştır (McNeill, 2002: 763-789; Faulkner, 2012: 266). 


\begin{tabular}{|c|c|c|c|c|c|c|c|}
\hline 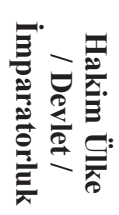 & 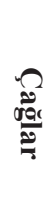 & 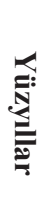 & 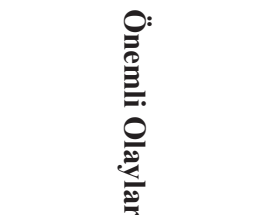 & 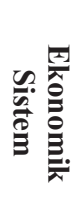 & 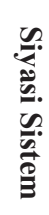 & 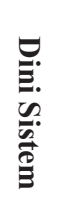 & 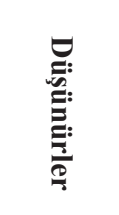 \\
\hline \multirow{8}{*}{ 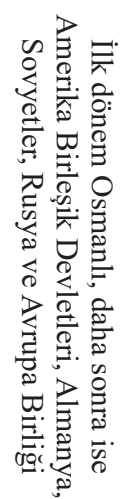 } & \multirow{8}{*}{ 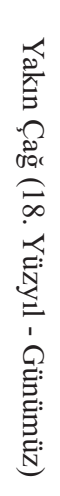 } & \multirow{8}{*}{$\stackrel{N}{\longleftarrow}$} & 11 Eylül Saldırısı & \multirow{8}{*}{ 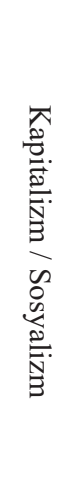 } & \multirow{8}{*}{ 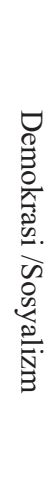 } & \multirow{8}{*}{ 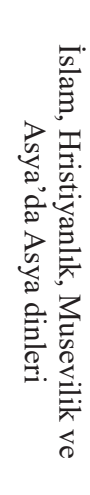 } & \multirow{8}{*}{ 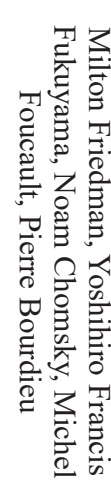 } \\
\hline & & & Arap Bahar1 & & & & \\
\hline & & & Büyük Tsunami & & & & \\
\hline & & & Irak Savaş1 & & & & \\
\hline & & & Higgs Bozonu & & & & \\
\hline & & & Geniş Bant İnternet & & & & \\
\hline & & & Sosyal Medya & & & & \\
\hline & & & $\begin{array}{c}\text { Kara deliğin varlığ } 1 \\
\text { ispatlandı }\end{array}$ & & & & \\
\hline
\end{tabular}

21. y.y.'da El Kaide tarafından 11 Eylül 2001 tarihinde Amerika Birleşik Devletleri'nde yaşayan sivil ve askerleri hedef alan bir dizi terör saldırısı gerçekleşmiştir. Bu saldırılarda, 2.974 kişinin hayatını kaybettiği açıklanmıştır. Dönemin başkanı George W. Bush, 11 Eylül saldırılarını neden göstererek önce Afganistan, ardından da Irak'1 işgâl etmiştir. 14 Mart 2013'te CERN bilim insanları dünyanın nasıl meydana geldiğini tanımlayan parçacık olan Higgs Bozonu'nun varlığından emin olduklarını açıklayarak dünya tarihinin en önemli keşfini gerçekleştirmişlerdir. 21. y.y.'1n bir diğer önemli gelişmesi ise Mark Zuckerberg tarafından Harvard Üniversite'sine ait bir sosyal paylaşım sitesinin oluşturularak kısa sürede yayılmasıdır. Ardından Jack Dorsey tarafından geliştirilen Twitter kurularak sosyal medya hızla topluma entegre olmuştur. 20. y.y.'da mülkiyetin şekil değiştirerek fikir, yetenek, bilgi ve patent gibi entelektüel hal alması, 21. y.y.'da sosyal medyanın yaygınlaşması ile birlikte mülkiyetin, sahipleri tarafından topluma ulaşmasını kolaylaştırmıştır. Bireyler sahip oldukları düşünceleri kolaylıkla ve özgürce paylaşma alanı bulmuşlardır. Özellikle geniş bant internet sisteminin yaygınlaştırılması ile paylaşımlar çok hızı bir biçimde sağlanabilmektedir. Üretimde en değerli girdi bilgi, fikir ve icat olmuştur, bu bağlamda mülkiyetin giderek daha da bireysel hale geldiği ve sosyal medya ile aktarılan bir düşüncenin, bir cümlenin mülkiyet haline dönüştüğü açıkça görülmektedir. 2010 yılında ise İslam dünyasında Arap Baharı olarak bilinen 
süreç ile birlikte, protestolar halinde Arap halklarının demokrasi, özgürlük ve insan hakları talepleri ile ortaya çıkan siyasi ve silahlı hareketler başlamıştır. Halklar, özgürlük mücadelesi adı altında birçok Arap diktatörünü resmen devirmiştir. 10 Nisan 2019'da ABD Ulusal Bilim Vakfı kara deliğin fotoğrafının çekilerek varlığının ispatlandığını ve elde edilen sonuçların Einstein'ın Genel Görelilik kuramıyla uyumlu olduğunu açıkladı.

\section{Sonuç ve Değerlendirme}

Mülkiyet, tarihin her döneminde toplumsal yapıyı şekillendiren ve toplumsal yapının şekillenmesine neden olan önemli bir tartışma alanıdır. Bakır Çağı'ndan günümüze kadar birçok dönüşüme uğrayan mülkiyet kavramı, günümüze gelene kadar kapsamı genişlemiş ve önemli tartışma alanlarından biri olma özelliğini korumuştur.

Mülkiyet tarihsel süreç içerisinde değerlendirildiğinde yaşanan önemli olaylardan, ekonomik, siyasi ve dini sistemlerde yaşanan dönüşümlerden etkilenerek kapsamı genişlemiştir. Öyle ki Bakır Çağı'nda mülkiyet, toprak üzerinde yoğunlaşırken günümüzde taşınır ve taşınmaz mallar üzerinde yoğunlaşmakta, fikir, bilgi ve hatta sosyal medyanın yaygınlaşmasıyla birlikte cümleler üzerinde de mülkiyet söz konusu olmaktadır. Diğer yandan mülkiyet insanlık tarihi boyunca eşitsizliğin temel nedenlerinden biri olarak da görülmektedir. Sınıf ayrımlarına neden olan mülkiyet konusu itibariyle aile ile aktarıldığında ya da toplumda tek elde toplanmasıyla birlikte eşitsizlik makasının giderek açılmasına neden olmaktadır. Ancak günümüz neo-liberal politikalar ekseninde mülkiyetin tamamen ortadan kaldırılması mümkün gözükmemektedir. Çalışma, günümüz koşullarında mülkiyet kavramının yarattığı dönüşümleri dönemlerinde yaşanan sistemlerle birlikte geniş bir perspektifte değerlendirerek, temel noktaları tespit etmeyi amaçlamaktadır. Bu bağlamda mısır takviminden günümüze kadar yapılan incelemelerde mülkiyetin geçirdiği evreler;

Olayların kesin olarak tarihlendirildiği Bakır Çağı'nda ekonomik sistemin tarıma dayalı olması nedeniyle toprak, mülkiyetin temel unsuru olarak karşımıza çıkmaktadır. Tarihsel süreç içerisinde bilimsel gelişmeler ve önemli icatlarla birlikte ekonomi gelişmiş, ticaret ön plana çıkmış ve mülkiyetin kapsamı da genişlemiştir. Bakır Çă̆ı'nda toprak mülkiyetinin, Bronz Çă̆ı'nda toprak, hayvan ve köle mülkiyetine doğru genişlediği görülmektedir. Diğer yandan da yaşanan kuraklık nedeniyle ellerinde verimli tarımsal araziler barındıran toprak 
aristokrasisi doğmuştur. Tek tanrılı dinlerin doğmasıyla birlikte başlayan özel mülkiyet ve ortak mülkiyet kavramları tartışılmaya başlamış, ticaretin gelişmesiyle birlikte taşınır mallar üzerinde özel mülkiyet söz konusu olmuştur. Yine bu dönemde mülkiyet kanunlarca düzenlenmiştir. Demir çağında Çin felsefesinin altın çağıyla birlikte mülkiyetin toprağa dayalı olduğunu ifade etmek mümkündür. Diğer yandan Roma'nın dini sistemler üzerine yoğunlaşan bir yönetimi bulunması nedeniyle ailelerin kendilerine ait kutsal alanları olması mülkiyetin ailelere yayılmasına neden olmuştur. Yine bu dönemde ortak mülkiyet ve özel mülkiyet tartışmaları ön plandadır. Bu dönemde yetişen düşünürlerden Platon ortak mülkiyeti savunurken Aristo özel mülkiyetin daha çok çalışmayı da beraberinde getireceğini ifade etmektedir. Demir çağında İpek Yoluyla birlikte artan ticaret hacmi ise özel mülkiyetin yayılmasına neden olmuştur. Orta Çağ' da tarıma dayalı mülkiyet siyasi bir sisteme evrilmiştir. Feodalizmin siyasi bir organizasyon olmasıyla sınıflar, tüm toprakların kendine bağışlandığına inanan bir kral altında ise lortlar, senyörler, şövalyeler, vassalar ve köylülerin olduğu bir sınıf yapısına dönüşmüştür. Geç Orta Çağ'da bilimsel alanda yaşanan gelişmelerle birlikte sabit dümenlerin ve pusulanın Avrupa'da kullanımın yaygınlaşmasıyla haritacılık gelişmiş ve yeni yerler keşfedilmiştir. Bununla birlikte ekonomi gelişmiş ve feodalizmden gittikçe uzaklaşan bir ekonomik sistem söz konusu olmuştur. Poliçelerin ticarette kullanılması, sermayenin mobil olmasına neden olmuştur. Orta Çağ' da mülklerin çoğunun kilisenin elinde olduğu görülmekle birlikte, Yeni Çağ'da Luther, başlattığı protestoyla mülklerin kralların eline geçmesini sağlamıştır. Krallık mülklerin bir kısmını satmış bir kısmını da krallık mülkü olarak kabul edilmiştir. Luther özel mülkiyet savunucusu olmuştur. Bu dönemde Calvin de özel mülkiyeti desteklemiştir. Protestan Kalvinistlerin zenginleşmeyi başaran insanların tanrı tarafından seçildiğini ifade ederken mülkiyete sahip olmanın dini temellerini de atmış, özel mülkiyetin ahlaki karşılığını da inşa etmiştir. Bu gelişmeyle birlikte artık özel mülkiyetin önlenemez yükselişi sanayi devrimiyle birlikte en üst noktaya ulaşmışıtır.

Yakın Çağ' da bütün dünyada değişimi tetikleyen Buhar gücünün icadı ve daha sonra da bu yeni keşfin tekstil makinelerinde kullanılmasıyla birlikte Sanayi Devrimi ortaya çıkmıştır. Sanayi Devrimiyle birlikte önce Avrupa'da başlayan dönüşüm yavaş yavaş bütün toplumsal, ekonomik ve siyasi sistemlerin değişimine neden olmuştur. Dönemin önemli isimlerinden olan Adam Smith, emeğin mülkiyeti kurduğu düşüncesinden özel mülkiyetin gerekliliği üzerinde 
durmuştur. Liberal devletle birlikte sınıfsal ayrımlar işçi işveren üzerinde yoğunlaşırken, yaşanan kentleşme gibi toplumsal dönüşümler işsizlik, yoksulluk, açlık ve emek sömürüsü gibi toplumsal sonuçları ortaya çıkarmış, gelir dağılımında adaletsizliği artırmıştır. Böylece mülkiyetin tekelliği ve mutlaklığ1 söz konusu olmuştur. Fransız Devrimi ile aydınlanma çağına girilmiş ve feodalizm mülkiyet anlayışında var olan sınırlamalar da ortadan kalmıştır. Bir yandan fizyokratların da özel mülkiyeti savunduğu dönemde diğer yanda marksizmin ortak mülkiyete ilişkin görüşleri de ön plana çıkmıştır. Özel mülkiyeti reddeden Marks'ın görüşleri Sovyet Rusya'da hakim olsa da özel mülkiyetin dünyada yayıldığı ifade edilebilir. Yakın Çağ'da yaşanan ekonomik buhran sanayileşmiş ülkeleri kıskacı altına almıştır. Keynesyen politikaların sahneye çıktığı bu dönemde refah devleti uygulamaları ön plana çıkmıştır. Bilim ve teknolojide yaşanılan gelişmelerle birlikte küreselleşme ortaya çıkmış ve sınırlar ortadan kalmıştır. Bu dönemde yaşanan iki dünya savaşı sonucunda ise sömürgecilik sona ermiştir. İnternetin keşfiyle de mülkiyet anonim şirketlerde ortak mülkiyet halini almıştır. Ortak mülkiyet içerisinde tasarrufları yöneten yöneticiler ile bu tasarruflardan yararlanan hissedarlar ortaya çıkmış, Dolayısıyla yararlanan ve kullanan birbirinden ayrılmıştır. Bu dönemde bilginin önemi artmış ve mülkiyet de bu bağlamda fikir, yetenek, bilgide yoğunlaşmıştır. 21 . y.y.' da sosyal medyanın ortaya çıkması ve muazzam bir biçimde yayılmasıyla birlikte; mülkiyete konu olan bilgi ve fikir gibi alanların yayılımının hızı saniyelere inmiş ve bireylerin paylaşımları onların mülkiyetlerine dair olmuştur. Paylaşılan bilgi hızı ve niteliği fark etmeksizin mülkiyete dair hale gelmiştir.

Çalışmada da görüldüğü üzere mülkiyet yaşanan gelişmelerle birlikte sürekli değişime uğramıştır. Önceleri bu değişimler dini sistemler, siyasi sistemler, ekonomik sistemlerle birlikte ortaya çikarken günümüzde teknolojik gelişmelerin ön plana çıktığı görülmektedir. İçinde bulunduğumuz Çağ'da mülkiyet, özel mülkiyet ve ortak mülkiyete dair hale gelmişken özel mülkiyetin önlenemeyen yükselişi, sınıfsal ayrımı pekiştirmekte ve refah devleti uygulamalarıyla bu ayrımdan kaynaklanan dezavantajlar en aza indirgenmeye çalışılmaktadır. Ancak neo liberal politikalar ekseninde sınırlı kalan refah devleti uygulamalarıla sınıfsal ayrım artarak devam etmektedir. Mülkiyet yaşadığı dönüşümlerle birlikte şekil değiştirse de sınıfsal farklılıkların temel nedenlerinden biri olma özelliğini taşımaktadır ve yaşanılan dönüşümlerin devam edeceği de aşikardır. Bu bağlamda konu ile ilgili değerlendirmeler tarihsel perspektifte kendi çağına uygun olarak gerçekleştirilmeli, yaşanılan değişimlerin birbirlerini tetiklediği 
göz ardı edilmemelidir. Bu bağlamda mevcut çalışma, yapılacak mülkiyet çalışmalarına geniş bir perspektifte değerlendirme imkanı sağlamayı amaçlamaktadır.

Finansal Destek: Yazarlar bu çalışma için finansal destek almamışlardır. 


\section{Kaynakça/References}

Arnold, D. (1995). Coğrafi keşifler tarihi. Çev Osman Bahadır. İstanbul: Alan Yayıncılık. Barber, M. (2006). Yeni şövalyelik tapınak tarikatinin tarihi. İstanbul: Kabalcı Yayınevi.

Briant, P. (2002). From Cyrus to Alexander a history of the Persian Empire. Indiana: Histoire de I'Empire perse by Librairie Artheme Fayard.

Brier, B. (1999). The history of Ancient Egypt course guidebook. US: The Great Courses.

Chapra, M. U. (2006). İbn-i Haldûn'un gelişme teorisi günümüz islâm dünyasının düşük performansına izahta yardımcı olur mu? Íslam Araştırmaları Dergisi, 16, 205-243.

Collins, J. C. (2007). The Hittites and their world. Atlanta: Society of Biblical Literature.

Dalkılınç, İ. (1998). İbn-i Haldun'un mülkiyet anlayışı. Sosyoloji Konferansları Dergisi, $25,71-91$.

Dougherty, R. J. (2003). Catholicism and the Economy: Augustine and Aquinas on Property Ownership. Journal of Markets \& Morality, 6(2), 479-495.

Erdem, B. (2012). İktisadi düşünceler tarihi. Eskişehir: Anadolu Üniversitesi Yayınları, Yayin No: 2617.

Ersoy, A. (2008). İktisadi teoriler ve düşünceler tarihi. Ankara: Nobel Yayın Dağıtım.

Etgü, M. A. (2008). Marksist mülkiyet yaklaşımı. Erzincan Üniversitesi Hukuk Fakültesi Dergisi, 12, 113-133.

Faulkner, N. (2012). Marksist dünya tarihi neandertallerden neoliberallere. İstanbul: Yordam Kitap.

Finkelstein, I. (2003). the forgotten kingdom the archaelogy and history of northern israel. Atlanta: The Society of Biblical Literature.

Friedman, H. H., \& Langbert, M. (2000). Abraham as a transformational leader. EJournal of Leadership Studies, 7, 88-95.

Güriz, A. (1969). Teorik açıdan mülkiyet sorunu. Ankara: Ankara Üniversitesi Hukuk Fakültesi Yayınları.

Hacak, H. (2005). İslâm hukuk düşüncesinde özel mülkiyet anlayışı. Marmara Üniversitesi Illâhiyat Fakültesi Dergisi, 29, 99-120.

Hobsbawn, E. J. (2003). Sanayi ve imparatorluk. (A. Ersoy, çev), Ankara: Dost Kitapevi.

Kılıç, R. ve Demirçelik, M. (2011). Mülkiyet kavramının tarihsel gelişim sürecinde ortaçağ ve reform hareketi. Dumlupınar Üniversitesi Sosyal Bilimler Dergisi, 30, 181-190.

King, F. (2008). A Comprehensive Chronicle of World History $-136,000$ To +1399 The Rise Of Civilizations And Cultures, A Comprehensive Chronicle of World History. I of IV, 1-264.

Kopier, K. (2010). Mesopotamia the world's earliest civilisation. New York: Britannica Educational Publishing. 
Köktürk, E. (2004). Haritacılığın 5000 yıllık yürüyüşü tarihsel süreç gelişme dinamikleri I. bölüm: Babiller'den antik çağa. Jeodezi, Jeoinformasyon ve Arazi Yönetimi Dergisi, 90, 32-35.

Kuiper, K. (2011). Ancient Rome from Romulus and Remus to the visigoth invasion. New York: Britannica Educational Publishing.

Leick, G. (2003). Historical dictionary of Mesopotamia. UK: The Scarecrow Press, Inc.

Marx, K., \& Friedrich, E. (1998). Komünist parti manifestosu. Ankara: Sol Yayınları.

Marriot, E. (2015). Bir nefeste dünya tarihi. (Yılgür E., Çev.). İstanbul: Maya Kitap.

Podany, A. H., (2018). Ancient Mesopotamia life in the Gradle of civilization course guidebook. US: The Great Courses.

Ponting, C. (2011). Yeni bir bakış açısıyla dünya tarihi. İstanbul: Alfa Basım Yayın.

Roosevelt, C. H. (2012). Iron Age Western Anatolia: The Lydian Empire and Dynastic Lycia, (D. Potts, çev). A Companion to the Archaeology of the Ancient Near East. Blackwell Companions to the Ancient World. MA: Blackwell Publishing.

Scott, J. C. (2018). The Phoenicians and the Formation of the Western World. Comparative Civilizations Review, 78, 24-40.

Şeker, S. ve Şeker F. (2019). Token'lardan çivi yazılı kil tabletlere: Yazının icadında muhasebenin izleri. Accounting and Financial History Research Journal. 16, 86-110.

Smith, A. (1997). Ulusların zenginliği. (Yunus A, Bakırcı M., Çev.), İstanbul: Alan Yayıncilik.

Topal, A. (2007). Latin Amerikayı anlamak. İstanbul: Yordam Kitap.

Ülgen, P. (2010). Ortaçağ Avrupasında Feodal Sisteme Genel Bir Bakış. Mukaddime, 1, $1-17$.

Warrier, M. (2007). Faith Guides for Higher Education A Guide to Hinduism. UK: Subject Centre for Philosophical and Religious Studies. 